NBER WORKING PAPER SERIES

\title{
SOCIAL SECURITY PROGRAMS AND RETIREMENT AROUND THE WORLD: WORKING LONGER - INTRODUCTION AND SUMMARY
}

\author{
Courtney Coile \\ Kevin S. Milligan \\ David A. Wise \\ Working Paper 24584 \\ http://www.nber.org/papers/w24584 \\ NATIONAL BUREAU OF ECONOMIC RESEARCH \\ 1050 Massachusetts Avenue \\ Cambridge, MA 02138 \\ May 2018
}

This paper is part of the National Bureau of Economic Research's International Social Security (ISS) Project, which is supported by the National Institute on Aging (grants P01 AG012810 and P30-AG012810). We thank the members of the other country teams in the ISS project for comments that helped to shape this paper. The views expressed herein are those of the authors and do not necessarily reflect the views of the National Bureau of Economic Research.

At least one co-author has disclosed a financial relationship of potential relevance for this research. Further information is available online at http://www.nber.org/papers/w24584.ack

NBER working papers are circulated for discussion and comment purposes. They have not been peer-reviewed or been subject to the review by the NBER Board of Directors that accompanies official NBER publications.

(C) 2018 by Courtney Coile, Kevin S. Milligan, and David A. Wise. All rights reserved. Short sections of text, not to exceed two paragraphs, may be quoted without explicit permission provided that full credit, including $(\odot$ notice, is given to the source. 
Social Security Programs and Retirement Around the World: Working Longer - Introduction and Summary

Courtney Coile, Kevin S. Milligan, and David A. Wise

NBER Working Paper No. 24584

May 2018

JEL No. J14,J26

\begin{abstract}
This is the introduction and summary to the eighth phase of an ongoing project on Social Security Programs and Retirement Around the World. This project, which compares the experiences of a dozen developed countries, was launched in the mid 1990s following decades of decline in the labor force participation rate of older men. The first several phases of the project document that social security program provisions can create powerful incentives for retirement that are strongly correlated with the labor force behavior of older workers. Subsequent phases of the project have explored disability program provisions and their effects on retirement as well as potential obstacles to promoting work at older ages, including whether there is a link between older employment and youth unemployment and whether older individuals are healthy enough to work longer.
\end{abstract}

In the two decades since the project began, the dramatic decline in men's labor force participation has ended and been replaced by sharply rising participation rates. Older women's participation has been rising as well. In this eighth phase of the project, we explore this phenomenon of working longer. We document trends in participation and employment and also consider factors that may help to explain these changes in behavior. We conclude that social security reforms as well as other factors such as the movement of women into the labor force have likely played an important role.

Courtney Coile

Department of Economics

Wellesley College

106 Central Street

Wellesley, MA 02481

and NBER

ccoile@wellesley.edu

Kevin S. Milligan

Vancouver School of Economics

University of British Columbia

6000 Iona Drive

Vancouver, BC V6T 1L4

CANADA

and NBER

kevin.milligan@ubc.ca
David A. Wise

NBER

1050 Massachusetts Avenue

Cambridge, MA 02138

dwise@nber.org 


\section{Project Overview}

Through the coordination of work of a team of analysts in twelve countries for nearly twenty years, the International Social Security (ISS) project has used the vast differences in social security programs across countries as a natural laboratory to study the effects of retirement program provisions on the labor force participation of older persons. The project's first several phases (Gruber and Wise, 1999, 2004, and 2007) documented the strong relationship across countries between social security incentives and older men's labor force participation, confirmed this relationship in microeconomic analysis, and estimated the labor market and fiscal implications of social security reform. Later volumes have examined the relationship between disability insurance program provisions, health, and retirement (Wise, 2012 and 2016) and explored whether older employment affects youth unemployment (Gruber and Wise, 2010) and whether older workers are healthy enough to work longer (Wise, 2017). This analysis is the eighth phase of the ongoing project, and it is focused on recent trends in labor force participation and potential explanations for these changes in behavior.

The results of the ongoing project are the product of analyses conducted for each country by analysts in that country. Researchers who have participated in this phase of the project are listed first below; those who have participated in prior phases are listed second in italics.

\begin{tabular}{|c|c|}
\hline Belgium & $\begin{array}{l}\text { Alain Jousten, Mathieu Lefèbvre, Arnaud Dellis, Raphaël } \\
\text { Desmet, Sergio Perelman, Pierre Pestieau, and Jean- } \\
\text { Philippe Stijns }\end{array}$ \\
\hline Canada & $\begin{array}{l}\text { Kevin Milligan, Tammy Schirle, Michael Baker and } \\
\text { Jonathan Gruber }\end{array}$ \\
\hline Denmark & $\begin{array}{l}\text { Paul Bingley, Nabanita Datta Gupta, Peder J. Pedersen and } \\
\text { Michael Jørgensen }\end{array}$ \\
\hline France & $\begin{array}{l}\text { Didier Blanchet, Antoine Bozio, Corinne Prost, Muriel } \\
\text { Roger, Luc Behaghel, Thierry Debrand, Ronan Mahieu, } \\
\text { Louis-Paul Pelé, Melika Ben Salem, and Emmanuelle } \\
\text { Walraet }\end{array}$ \\
\hline Germany & $\begin{array}{l}\text { Axel Börsch-Supan, Irene Ferrari, Tabea Bucher-Koenen, } \\
\text { Hendrik Jürges, Simone Kohnz, Giovanni Mastrobuoni, } \\
\text { Johannes Rausch, Reinhold Schnabel, Morten Schuth and } \\
\text { Lars Thiel }\end{array}$ \\
\hline Italy & $\begin{array}{l}\text { Agar Brugiavini, Giacomo Pasini, Guglielmo Weber and } \\
\text { Franco Peracchi }\end{array}$ \\
\hline Japan & $\begin{array}{l}\text { Takashi Oshio, Satoshi Shimizutani, Emiko Usui, Mayu } \\
\text { Fujii, Akiko Sato Oishi and Naohiro Yashiro }\end{array}$ \\
\hline
\end{tabular}




\begin{tabular}{|c|c|}
\hline Netherlands & Adriaan Kalwij, Arie Kapteyn and Klaas de Vos \\
\hline Spain & $\begin{array}{l}\text { Pilar García Gómez, Sergi Jiménez-Martín, Judit } \\
\text { Vall-Castelló, Michele Boldrín and Franco Peracchi }\end{array}$ \\
\hline Sweden & $\begin{array}{l}\text { Lisa Laun, Mårten Palme, Per Johansson, and Ingemar } \\
\text { Svensson }\end{array}$ \\
\hline United Kingdom & $\begin{array}{l}\text { James Banks, Carl Emmerson, Gemma Tetlow, Richard } \\
\text { Blundell, Antonio Bozio, Paul Johnson, Costas Meghir and } \\
\text { Sarah Smith }\end{array}$ \\
\hline United States & $\begin{array}{l}\text { Courtney Coile, Kevin Milligan, David Wise, Jonathan } \\
\text { Gruber and Peter Diamond }\end{array}$ \\
\hline
\end{tabular}

An important goal of the project has been to present results that are as comparable as possible across countries. Thus the papers for each phase are prepared according to a detailed template that we develop in consultation with country participants. In this introduction, we summarize the collective results of the country analyses and borrow freely from the country papers. In large part, however, the results presented in the introduction could only be conveyed by combined analysis of the data from each of the countries. The country papers themselves present much more detail for each country and, in addition to the common analyses performed by all countries, often present country-specific analysis relevant to each particular country. 


\section{Introduction}

At the turn of the 20th century, a majority of men in developed economies worked even at the oldest ages. As Costa (1998) documents, the labor force participation rate of men age 65 and above in 1900 was 65 percent in the US, 61 percent in Britain, 58 percent in Germany, and 54 percent in France. ${ }^{1}$ Given the relatively short life expectancies of the time, many men of this era would have spent few if any years in retirement.

By the late $20^{\text {th }}$ century, however, work past age 65 had become the exception rather than the rule. The share of men age 65 to 69 in the labor force in 1995 was only 4 percent in Germany, 5 percent in France, 15 percent in the UK, and 27 percent in the US. Including men age 70 and above (to match the earlier figures) would drive these values lower still. With life expectancies at older ages rising quickly over the same period-by 4.3 years for men at age 65 in the US during the 20th century (Bell and Miller 2002), for example_retirement emerged as a distinct and important phase of life.

The growth of public pension programs has long been a leading candidate to explain this decline in older men's participation. Germany introduced the world's first old age social insurance program in 1889 and other developed countries followed suit over the next several decades. Over time, many countries expanded their programs to cover more of the work force, provide benefits for new categories of individuals such as survivors and the disabled, and offer more generous benefits.

The International Social Security (ISS) project was started in the mid-1990s, against this backdrop of decades of decline in older men's work and growth of public pension programs in many developed countries. The project sought to use the vast differences in social security programs across countries as a natural laboratory to study the effects of retirement programs on the labor force participation of older persons.

As it turns out, the launch of the ISS project coincided with the end of the century-long decline in men's labor force participation. Not only was the declining trend arrested, but the employment rates rose tremendously in many countries. This is illustrated for men ages 60 to 64 in Figure 1. While the exact year of the trough varies across country, labor force participation has risen by an average of 17 percentage points in the twelve ISS countries between its lowest point and 2014, as noted on Table 1. Participation rose in every country but the magnitude of the increase varied, from 7 points in Japan and Spain to 35 points in Germany and 44 points in the Netherlands.

1 These data are for the years 1895-1901, depending on the country; see Costa (1998) for details. 
Figure 1: LFP of Men Ages 60-64, 1980-2014

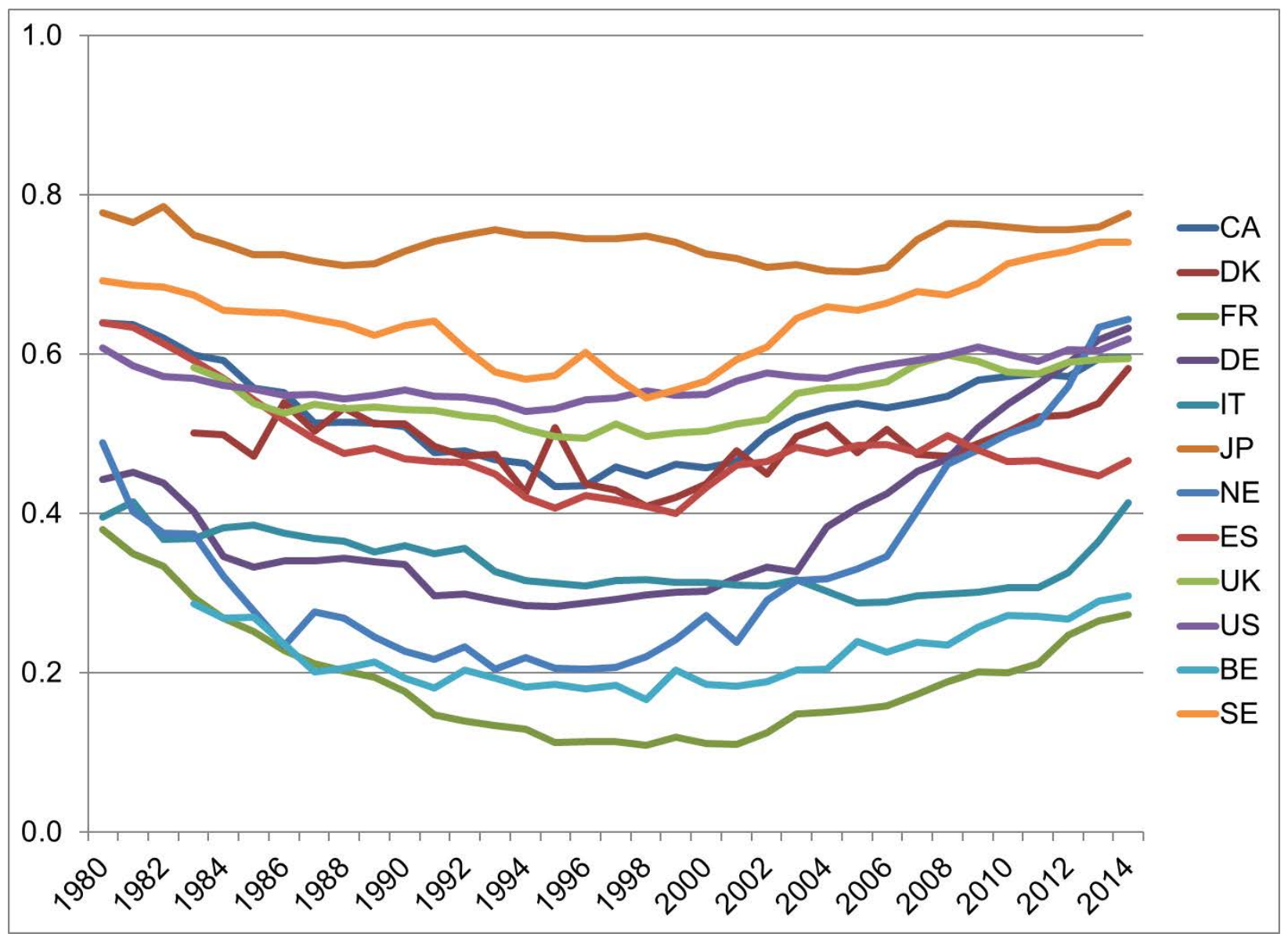

Table 1: Increase in Labor Force Participation of Men Age 60-64, Trough to 2014

\begin{tabular}{lcccc}
\hline Country & Year of Min LFP & Min LFP & 2014 LFP & Difference \\
\hline Belgium & 1998 & 0.167 & 0.297 & 0.130 \\
Canada & 1995 & 0.434 & 0.596 & 0.162 \\
Denmark & 1998 & 0.409 & 0.582 & 0.173 \\
France & 1998 & 0.109 & 0.273 & 0.164 \\
Germany & 1995 & 0.284 & 0.633 & 0.349 \\
Italy & 2005 & 0.288 & 0.413 & 0.125 \\
Japan & 2005 & 0.703 & 0.776 & 0.073 \\
Netherlands & 1993 & 0.204 & 0.644 & 0.440 \\
Spain & 1999 & 0.400 & 0.466 & 0.066 \\
Sweden & 1998 & 0.545 & 0.740 & 0.195 \\
UK & 1996 & 0.495 & 0.595 & 0.100 \\
US & 1994 & 0.528 & 0.619 & 0.091 \\
\hline Average & & 0.381 & 0.553 & 0.172 \\
\hline
\end{tabular}


Why did so many countries experience a substantial increase in men's labor force participation at this particular time, following a century of earlier withdrawal from the labor force? Why was the increase larger in some countries than others? The answers to these questions are pivotal as countries seek solutions to the fiscal and retirement security challenges posed by the expansion in lifespans and may want to encourage further increases in elderly labor supply. If the turnaround in labor supply is driven by demographic or global economic trends, then any one country's direct policy choices will change little. On the other hand, if policy changes around social security programs have contributed significantly to the turnaround in labor force participation, then further direct policy measures might be effective in prolonging work lives.

The goal of this phase of the ISS project is to begin to answer these questions by documenting the changes in labor force participation and employment of older men and women from 1980 to the present and exploring the factors that may have contributed to these changes. The methods we use are primarily descriptive, as we examine trends over time in labor supply and in those factors that may affect it. By investigating these issues in a cross-country context, we can gauge the universality of trends observed in individual countries. We can also potentially build a stronger case that a certain factor, say improving health or education, may be contributing to changes in participation if we observe larger changes over time in participation in those countries where the factor also changed more rapidly. In some cases, we highlight interesting case studies from individual country chapters that suggest a role for a particular factor, although the individual chapters offer much more of this as well as additional analyses undertaken by the authors to shed light on questions of particular interest in their context.

Our analysis provides some indication of which factors are more important. For health and education, we find little evidence that these are strong contributing factors. Health and education generally improved both in times when labor force participation rates were falling and when they were rising. Further, countries experiencing greater improvements in health and education over time did not see bigger increases in older worker labor market participation, in general. The expansion of women in the workforce over the last generation, however, does appear to have had an impact not just in explaining the work behavior of women but also the work behavior of men. Countries with a larger expansion of female labor force participation see men staying in the labor market longer. Finally, institutional factors embedded in social security programs seem very important in explaining the older-age working patterns in some individual countries.

\section{Trends in Labor Force Participation and Employment}

We begin by describing trends in labor force participation and employment for men and women ages 55 to 69 in the twelve ISS countries from 1980 to the present. Figures 2 and 3 illustrate these trends for men and women, respectively. 
Figure 2: Labor Force Participation and Employment, Men 55-69, 1980-2014
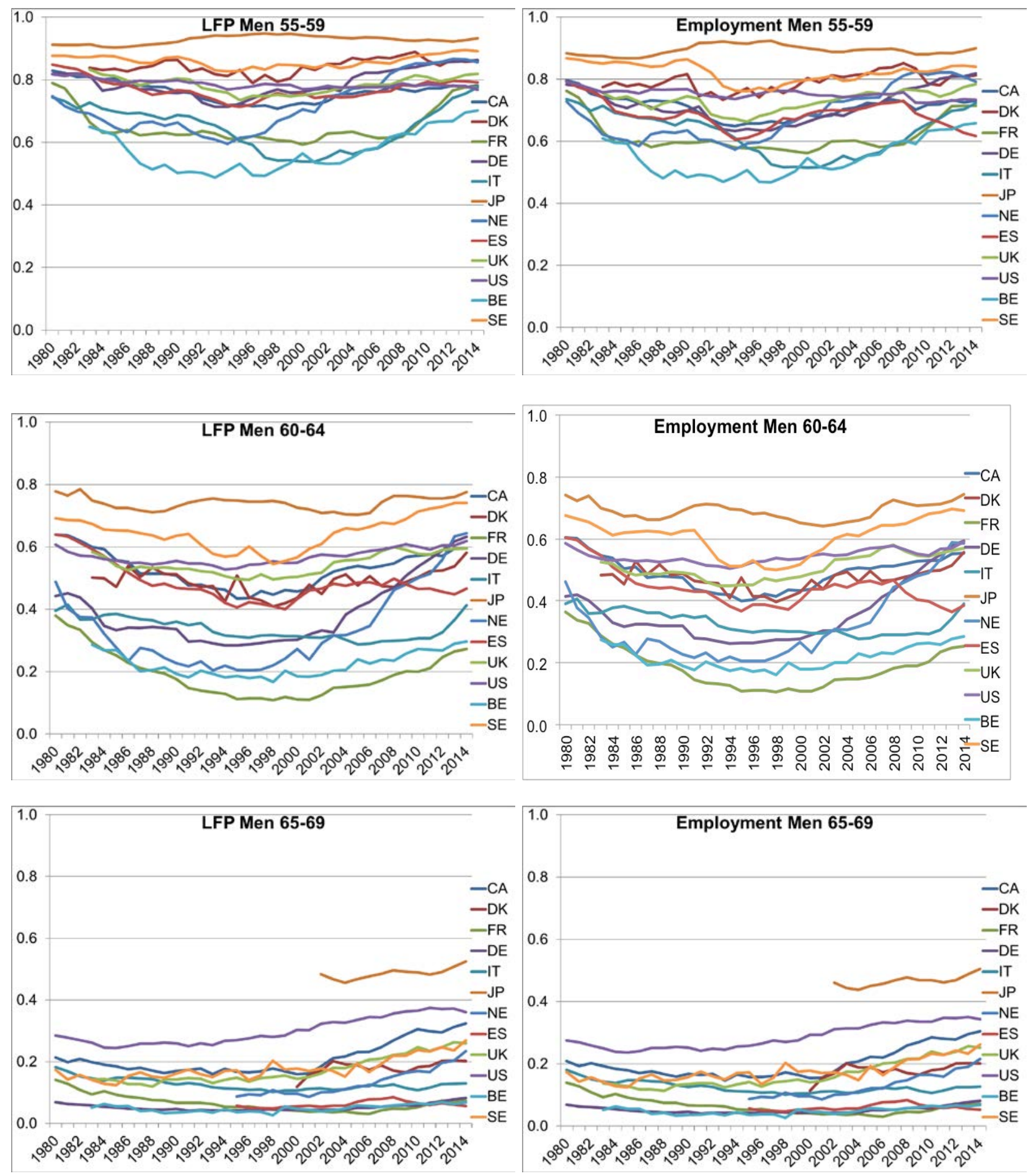
Patterns in participation for men 55 to 59 are broadly similar to those for men 60 to 64 , discussed above, though the magnitudes of the changes are somewhat smaller. As before, most ( 8 of 12) countries reached the trough of participation during the period 1993 to 1998 . The average increase in participation from the trough to 2014 is 13 percentage points, an increase about three-quarters as large as that seen for men ages 60 to 64 (17 points). As before, the size of the change varies across countries, as seen in Table 2. There was no change in the US, as participation remained relatively constant between the mid-1990s and 2014, and an increase of only 3 points in Japan, which consistently has the highest participation rate of all of the countries. By contrast, participation rose by 7 to 8 points from the trough to 2014 in Canada, Denmark, Spain, and the UK, and by 15 to 26 points in Belgium, France, Germany, Italy, and the Netherlands.

Table 2: Increase in Labor Force Participation, Trough to 2014

\begin{tabular}{llllllll} 
& \multicolumn{7}{c}{ Increase in LFP, Trough to 2014 } \\
\cline { 2 - 4 } \cline { 6 - 7 } Country & $\mathbf{5 5 - 5 9}$ & $\mathbf{6 0 - 6 4}$ & $\mathbf{6 5 - 6 9}$ & & $\mathbf{5 5 - 5 9}$ & $\mathbf{6 0 - 6 4}$ & $\mathbf{6 5 - 6 9}$ \\
\cline { 2 - 3 } Belgium & 0.214 & 0.130 & 0.041 & & 0.418 & 0.159 & 0.019 \\
Canada & 0.075 & 0.162 & 0.164 & & 0.304 & 0.250 & 0.138 \\
Denmark & 0.070 & 0.173 & & & 0.242 & 0.210 & \\
France & 0.184 & 0.164 & 0.042 & & 0.310 & 0.170 & 0.027 \\
Germany & 0.150 & 0.349 & 0.041 & & 0.395 & 0.296 & 0.024 \\
Italy & 0.237 & 0.125 & 0.026 & & 0.316 & 0.166 & 0.016 \\
Japan & 0.029 & 0.073 & & & 0.182 & 0.107 & \\
Netherlands & 0.261 & 0.440 & 0.148 & & 0.494 & 0.355 & 0.061 \\
Spain & 0.078 & 0.066 & 0.008 & & 0.367 & 0.181 & 0.015 \\
Sweden & 0.064 & 0.195 & 0.128 & & 0.148 & 0.254 & 0.135 \\
UK & 0.084 & 0.100 & 0.140 & 0.220 & 0.229 & 0.114 \\
US & 0.000 & 0.091 & 0.116 & 0.179 & 0.176 & 0.140 \\
\hline Average & 0.126 & 0.172 & 0.085 & 0.298 & 0.213 & 0.069 \\
\hline Notes: & & & & & &
\end{tabular}

Notes:

Denmark and Japan are omitted for the 65-69 age group because data series start after 2000. Data series for Spain and the Netherlands are included, but begin only in 1995.

For men ages 65 to 69, there is a somewhat different pattern across countries. The largest increases are in Canada, the Netherlands, Sweden, the UK, and the US. Except for Sweden and the Netherlands, these countries had relatively small increases in participation in the two younger age groups. The average increase among all the countries from trough to 2014 for this age group is 8.5 points, smaller than the average increase in the other age groups. 
Figure 3: Labor Force Participation and Employment, Women 55-69, 1980-2014
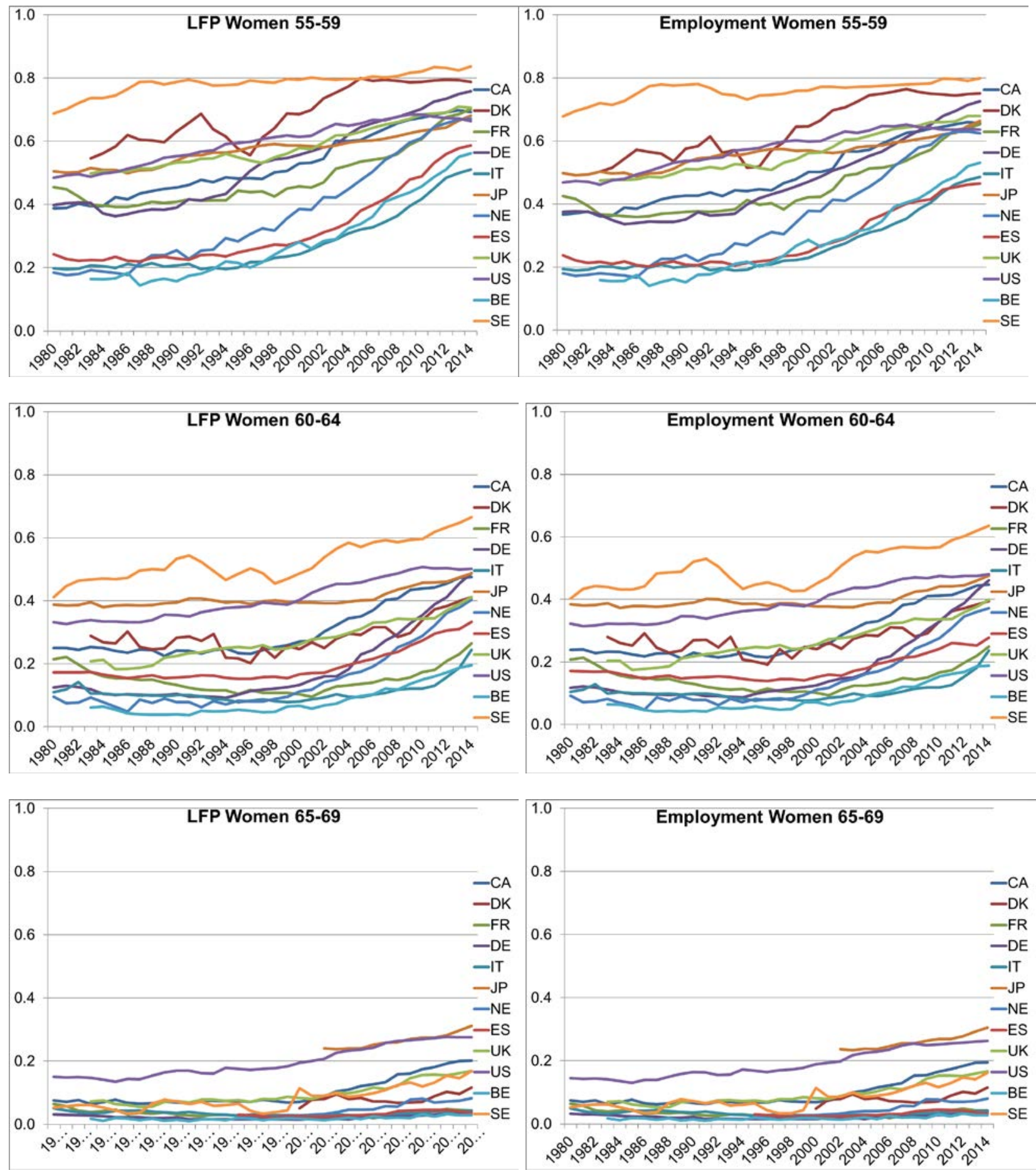

Finally, we can add the increases across the three age groups in each country as one way to gauge the overall rise in participation at ages 55 to 69. The Netherlands experienced by far the largest increase in participation ( 85 points), followed by Germany 
(54 points). The US and Spain had the smallest total increases (21 and 15 points), while the other countries fell in the middle (30 to 40 points).

Another finding from these figures is that while the employment rate is (unsurprisingly) slightly lower than the participation rate, trends over time in the two series are very similar. This is particularly true for the older age groups. The one exception is after the recent recession (2007 and beyond), where there is a bigger divergence between employment and participation for men age 55-59, particularly in Spain. This suggests that normal cyclical trends in unemployment (which is the difference between the employed group and the labor force group) are unlikely to be an important factor. Because trends in labor force participation and employment are largely similar, we focus on participation in the remainder of the analysis.

Patterns in women's labor force participation are quite different from those of men. For women age 55-59, the trough year is in the 1980s in all countries-in fact, it is 1980 or 1981 for about half the countries, which is essentially the beginning of our sample period. Thus, unlike the men's pattern of a U-shape that reaches bottom in the mid-1990s, here there is often no $U$, or only a shallow one with a trough in the mid1980s. The average increase in women's labor force participation from the trough to 2014 in this age group is also much larger, 30 points vs. 13 points for men. For women, it seems likely that any tendency to retire earlier over the first half of our sample period that might arise from the same factors that are affecting men is being swamped by ever increasing labor force participation among successive cohorts of women. ${ }^{2}$

There are notable differences across countries in the magnitude of the increase in participation over time, as seen in Table 2 . Increases appear to be inversely proportional to initial participation rates, leading to a converging trend across countries. Denmark, Japan, the UK, and the US had participation rates of around 50 percent in 1980, and all experienced increases of less than 25 percentage points by 2014. Meanwhile, Belgium and the Netherlands had participation rates below 20 percent in the early 1980 s and experienced increases of 40 to 50 percentage points.

At ages 60 to 64, there is similarly either no U-shape or one that appears relatively shallow compared to the pattern for men. The average increase in participation from trough to 2014 for this age group is 21 percentage points, still very large but smaller than the 30 point increase at ages 55 to 59 . The increase at ages 65 to 69 is smaller still, averaging 7 points. However, Canada, Sweden, the UK, and the US experienced increases about twice as large as the average in this oldest group, as was the case for men. Overall, labor force participation among women in all three age

2 See Goldin (2006) for an overview of the changes in women's employment, education, and family roles during the $20^{\text {th }}$ century. 
groups is now at an all-time high, and there is little suggestion in the figures that it has yet reached its peak.

\section{Factors that May Affect Labor Force Participation}

Next, we turn to exploring those factors that may help to explain the changes in labor force participation. In the discussion below, we consider a number of potential factors, including changes in mortality and health, education and occupation, unemployment, social security program provisions, and women's labor force participation (which may affect men's participation).

\section{Mortality and Health}

Health is a critically important factor in individual's retirement decisions, as established in early studies such as Diamond and Hausman (1984) and confirmed in more recent studies such as Wise (2016). It stands to reason that changes over time in the health of the older population may have had an impact on labor force participation.

Mortality rates offer a number of advantages as a measure of health. They can be measured consistently across countries and over time, generally quite precisely because they are typically based on vital statistics records for the full population rather than survey data. A clear disadvantage is that they may be an imperfect measure of work capacity at older ages, which is what is relevant for retirement decisions. ${ }^{3}$ However, Milligan and Wise (2012) find that there is a strong within-country relationship between changes over time in self-assessed health and changes in mortality. To the extent that self-assessed health may be a better measure of work capacity, this is reassuring. Time series on self-assessed health are unfortunately available for only about half of the ISS countries, so we do not use these data directly here, though some countries make use of them in their own chapters.

Mortality rates at older ages have declined substantially during the past several decades, as shown in Figure 4. For men, the average mortality rate at age 60 in 1980 was 1.7 percent. By 2011, this had dropped roughly in half, to 0.9 percent. ${ }^{4}$ Mortality improved notably and continuously throughout the period for all countries, with a

\footnotetext{
${ }^{3} \mathrm{~A}$ number of recent papers have explored the question of whether people are living healthier as well as longer lives. While studies such as Crimmins and Beltran (2011) have found that people are spending more years living with disease, studies such as Cutler et al. (2014) and Chernew et al. (2016) find that disability-free life expectancy is rising faster than life expectancy, indicating that disability is increasingly being compressed into a shorter period before death. It seems possible if not likely that disability would matter more for labor supply than disease, as some diseases may not interfere with work or can be managed with medication or lifestyle changes.
}

42011 is used here because it is the last year for which all countries (except Germany) have data; Germany is excluded from these calculations because its data series ends earlier. 
somewhat smaller absolute decrease in Japan, which had the lowest initial mortality rate. Mortality rates in 1980 for women were far lower than those for men, averaging 0.9 percent. By 2011, this value had fallen to 0.5 percent.

Figure 4: Mortality at Age 60, Men and Women, 1980-2014

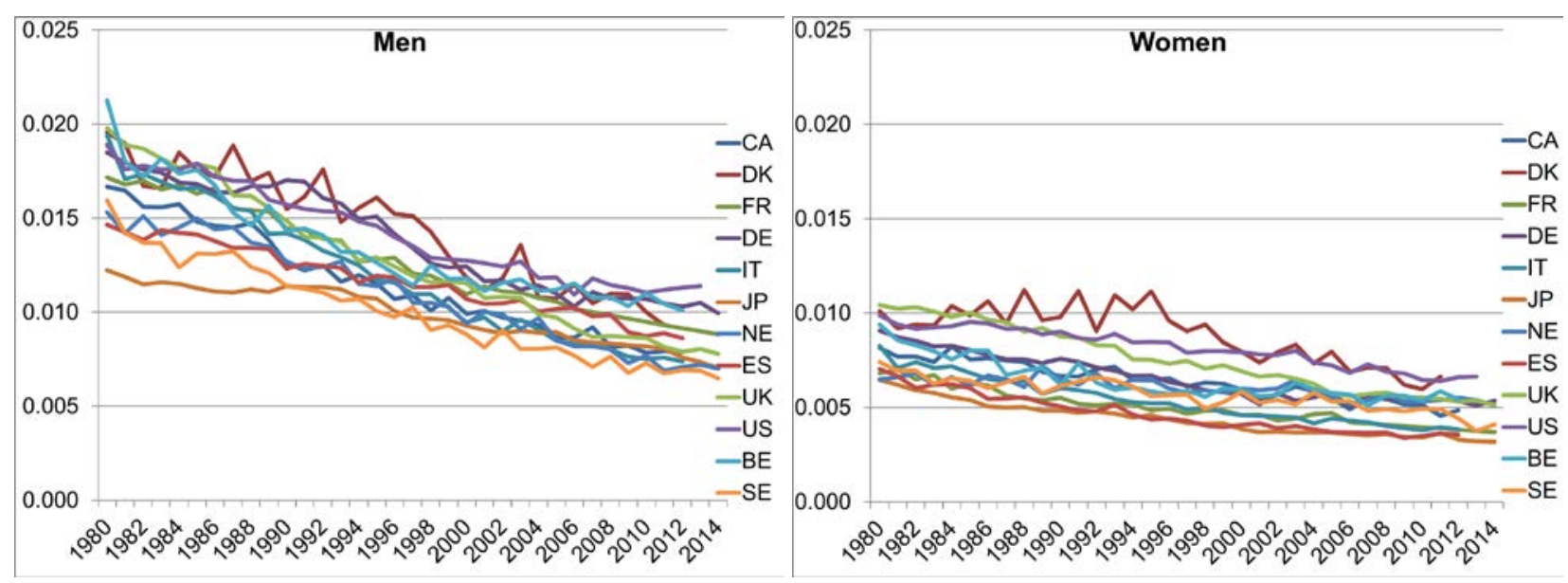

In establishing changes in mortality rates as a possible driver of changes in labor force participation, one is immediately confronted by the difficulty that labor force participation for men exhibits a U-shape with a trough in the mid-1990s, while mortality has improved continuously throughout this period. Thus, the hypothesis that rising participation since the mid-1990s has been driven by improving health would appear to be undercut by the fact that health was also improving during the earlier part of our sample period when participation was falling. For women, the lack of a U-shape in participation (or presence of a shallower $U$ ) makes this problem a bit less glaring. Nonetheless, even for women this constitutes weak evidence at best that changes in health may be driving changes in participation.

To continue to probe the plausibility of a causal relationship between mortality and labor force participation, in the left panel of Figure 5 we plot the change in participation for men 60 to 64 from 1995 to 2011 against the change in the mortality rate at age 60 over the same period. The slope is expected to be negative, as those countries in which the mortality rate fell by more are expected to have a larger increase in participation. In fact, the slope is negative, but this finding is not robust, as omitting Germany, which is an outlier in terms of its large increase in participation, yields a positive slope. For women, the slope is negative, as seen in the right panel of the figure. The magnitude of the effect for women indicates that moving from being the country with the smallest mortality improvement (no improvement) to that with the largest improvement (a drop of 0.4 percent over the 16-year period) is associated with an increase in participation of about 5 percentage points, or roughly one-third of the average increase of 14 points during this period. However, the lack of a robust effect for 
men casts doubt on the notion that this reflects a causal effect, as one would expect improvements in health to affect both genders in a similar way.

Figure 5: Change in LFP at 60-64 vs. Change in Mortality Rate, 1995-2011
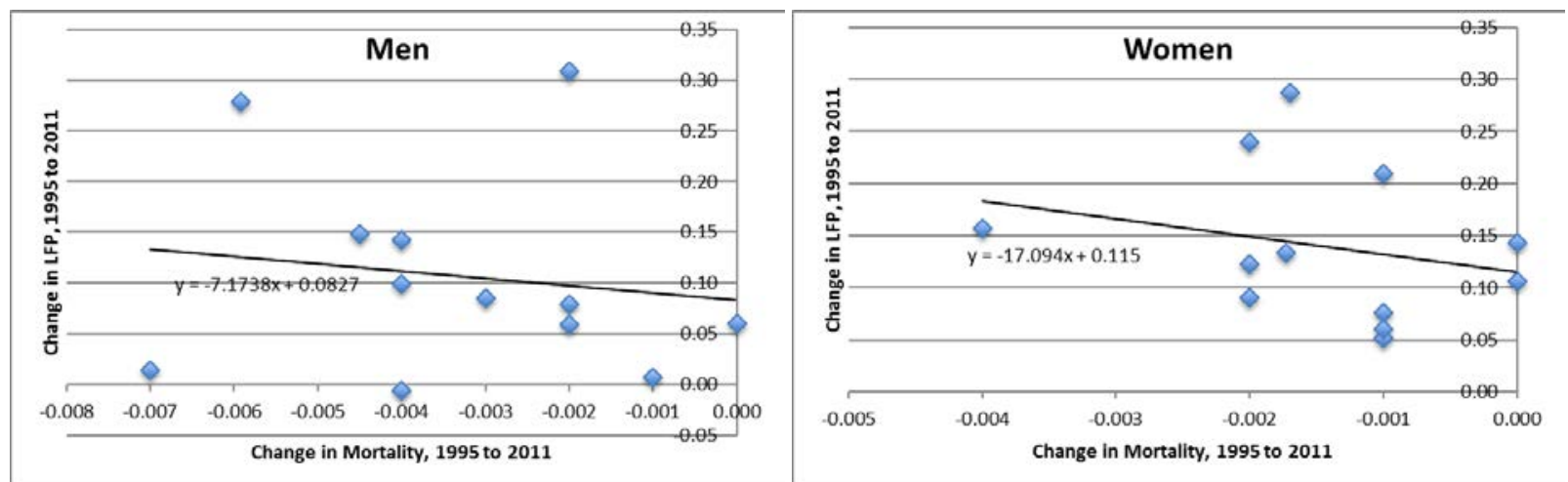

Overall, we find little evidence that improvements in health—as measured by mortality rates-are a driving force behind the increases in labor force participation over the past few decades. We base this assessment on the fact that there has been continuous improvement in mortality rates since 1980 while participation among men was falling for the first half of the sample period and rising for the second, and also on the inconsistent evidence for the hypothesis that countries with faster improvement in mortality since 1995 also experienced faster growth in labor force participation. Of course, we cannot rule out the possibility that the results would differ if we were able to examine other health measures beyond mortality that might be more directly tied to work capacity; unfortunately, the lack of consistent time series for such health measures in enough of the countries prevents us from exploring this further. Nonetheless, this analysis suggests that we need to look to other factors to explain recent increases in participation.

\section{Education and Occupation}

Education and occupation also offer promise as potential explanatory factors for changes in participation. Labor force participation rates at older ages tend to differ sharply by education-Coile et al. (2016) report that for men ages 55 to 64 in all ISS countries, those in the highest education group have participation rates 20 to 40 percentage points higher than those in the lowest education groups. Occupation is a closely related factor, since one reason for the strong relationship between education and participation may be that people with more education tend to have jobs that are less 
physically demanding, making it easier for them to work to older ages. ${ }^{5}$ If successive cohorts nearing retirement age have higher levels of education and are more concentrated in white collar occupations, this may tend to increase participation at older ages.

Figure 6 shows the share of men and women ages 55 to 64 who have a college education. Over the period 1980-2016, the share of men with a college education rises by 15 to 20 percentage points in virtually all countries, with the exception of Italy, where the increase is about 5 points. Compared to men, women have a lower share initially in 1980, but the rate of growth over time is quite similar. By 2012 (the last year for which we have complete data), the average share of men and women with a college degree across all the ISS countries is 26 and 21 percent, respectively.

Figure 6: Share of Men and Women 55 to 64 with a College Education, 1980-2014
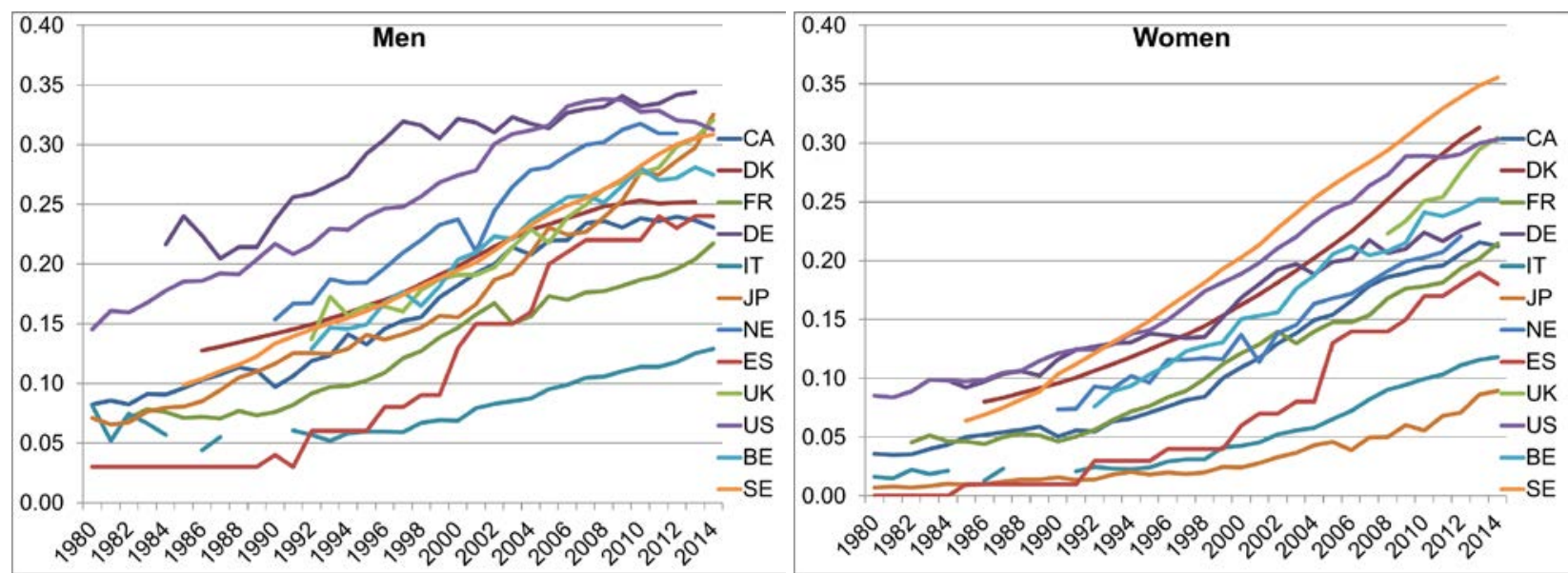

The share of men and women in blue collar occupations is shown in Figure 7 for countries where these data are available. There are large differences across countries at any point in time, which likely result as much from differences in the definition of blue collar in each country as from differences in the occupational composition of the work force. The changes over time within countries are of greater interest for our purposes. There are declines over time for men in most countries; France and Belgium, which have among the lowest rates of blue collar work as defined here, have only minimal declines. If we compare countries that have a similar share blue collar in 1980 in order to control for differences in definition, we see that the magnitude of changes over time varies by country. Italy and Spain, for example, have similarly high rates of blue collar work at the

\footnotetext{
${ }^{5}$ Belbase et al. (2016) argue that the notion that it is difficult for blue-collar workers to remain on the job at older ages and easy for white-collar workers to do so is too simplistic, and that it is "important to consider the particular abilities required by an occupation and whether these abilities decline significantly by the time workers reach typical retirement ages."
} 
beginning of the sample period, but the decrease is larger in Italy; Japan experiences a larger decrease than Germany. Results for women are largely similar, though the share blue collar for women is substantially lower than for men in some countries, including Canada, France, and the US.

Figure 7: Share of Men and Women 55 to 64 in Blue Collar Work, 1980-2014

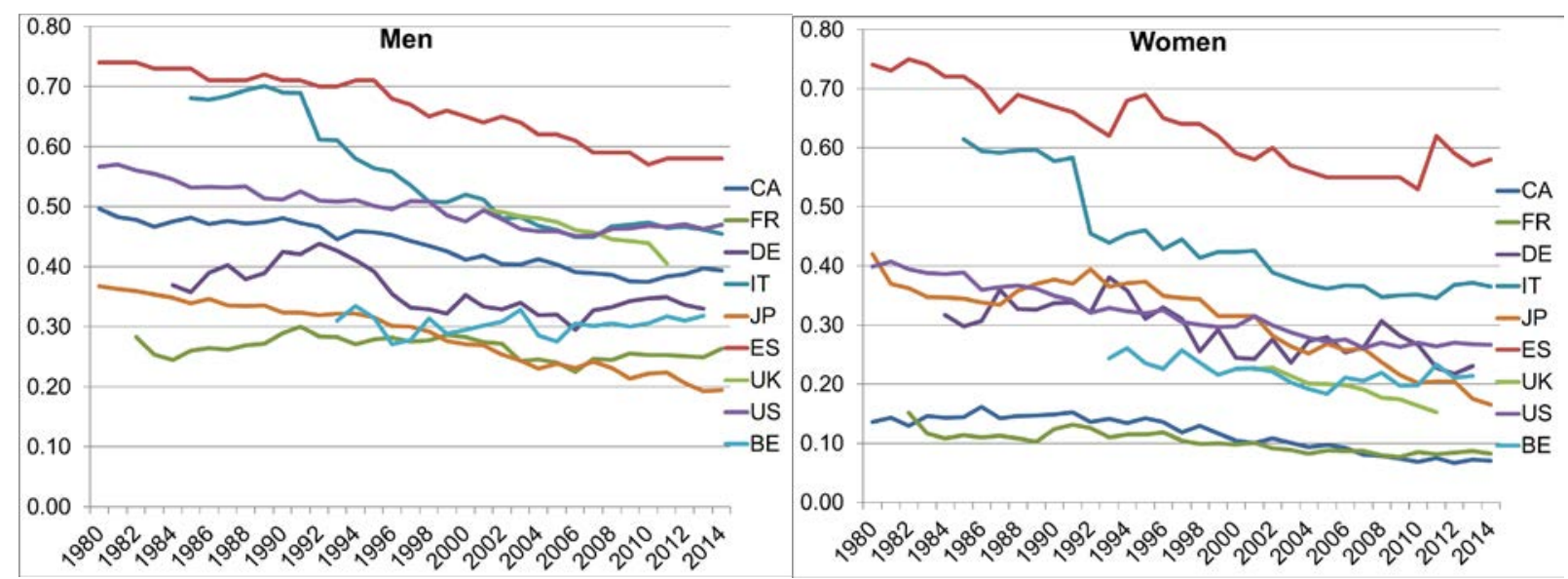

Could the rise in education and the decline in blue collar employment be driving changes in labor force participation over the past several decades? As with mortality, one challenge to this hypothesis is that the share of men with a college education is continuously rising during this period (and share in blue collar employment is continuously falling), while participation exhibits a U-shape. Put differently, while the data from the mid-1990s to the present is consistent with this theory-men are reaching retirement with more education and more likely to be in white collar employment and so are working longer-the data from the first half of the sample period is at odds with it. For women, the U-shape is muted so the conflict is less evident, but it remains difficult to draw any causal conclusion from this analysis.

We probe this relationship further by exploring whether countries that experienced a more rapid increase in the share of people with a college education also tended to have larger increases in participation since 1995. Here the expected slope is positive, but the actual slope for men is slightly negative. For women, the slope is positive; the magnitude suggests that if the change in share with college were 10 percentage points higher, participation would rise by an additional 1.5 points. 
Figure 8: Change in LFP at 60-64 vs. Change in Share with College, 1995-2012
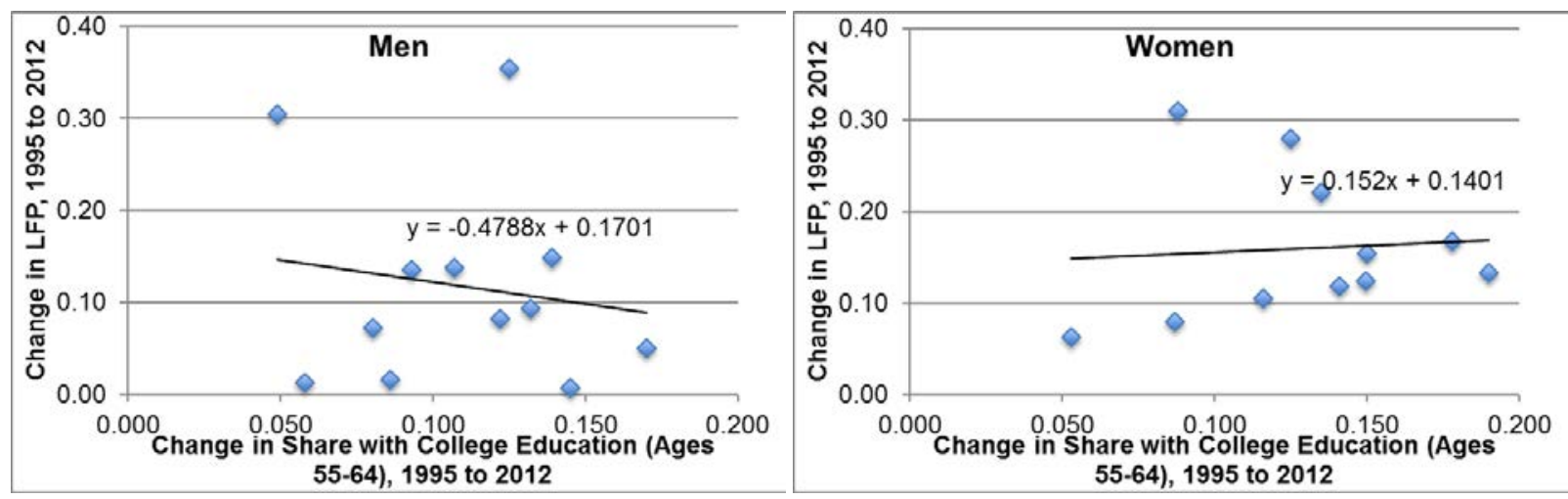

Overall, the results for education are much the same as for health. The simple time series data does not support the hypothesis that changes in health and education are driving changes in participation for men because they cannot explain the U-shape in men's participation. And there is inconsistent evidence as to whether larger changes in these factors since 1995 are associated with larger changes in participation. In sum, we find little evidence to support some of the most frequently suggested explanations for why workers are retiring later, namely that they are healthier and better educated.

Unemployment

We now turn to unemployment rates to explore what role, if any, differences in unemployment across countries or over time may have played in labor trends. If there were a mismatch between labor demand and labor supply underlying the shifts in employment, we expect it would be evident—at least transitorily—in the unemployment rates. We graph the unemployment rates for age 55-64 men and women in Figure 9 from 1980 to 2014.

Figure 9: Unemployment for age 55-64, Men and Women

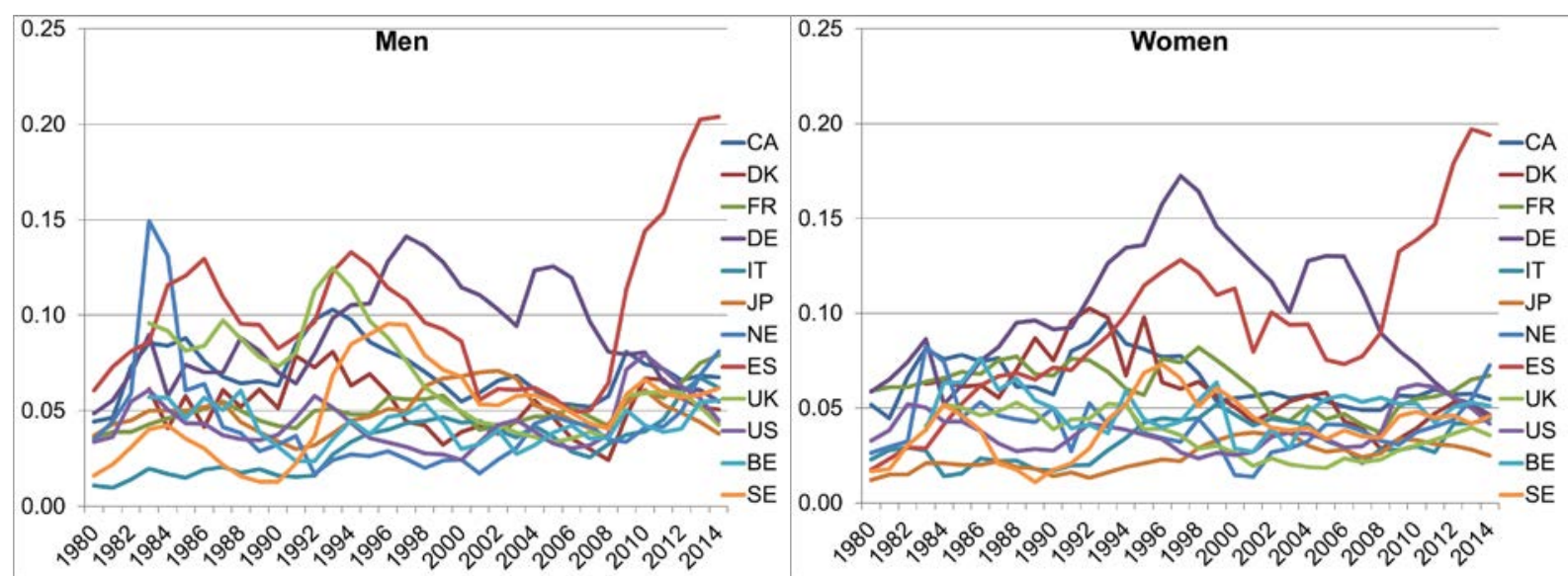


In ten of the twelve countries, the unemployment rate for older workers follows a more-or-less cyclical trend within a fairly narrow range over this time period. The case of Spain also follows this pattern-except the business cycle pattern was simply much stronger. As can be seen in Figure 10 below taken from the Spanish chapter, the unemployment rate for older workers in Spain mirrored the trends for all workers over most of this period. ${ }^{6}$ This elevated unemployment rate for older workers in Spain may help explain why the peak-to-trough labor force participation change in Spain is among the lowest in any of our countries for both sexes in Table 2, as some discouraged job seekers may have exited the labor force early rather than continuing to look for jobs.

\section{Figure 10: Unemployment in Spain}

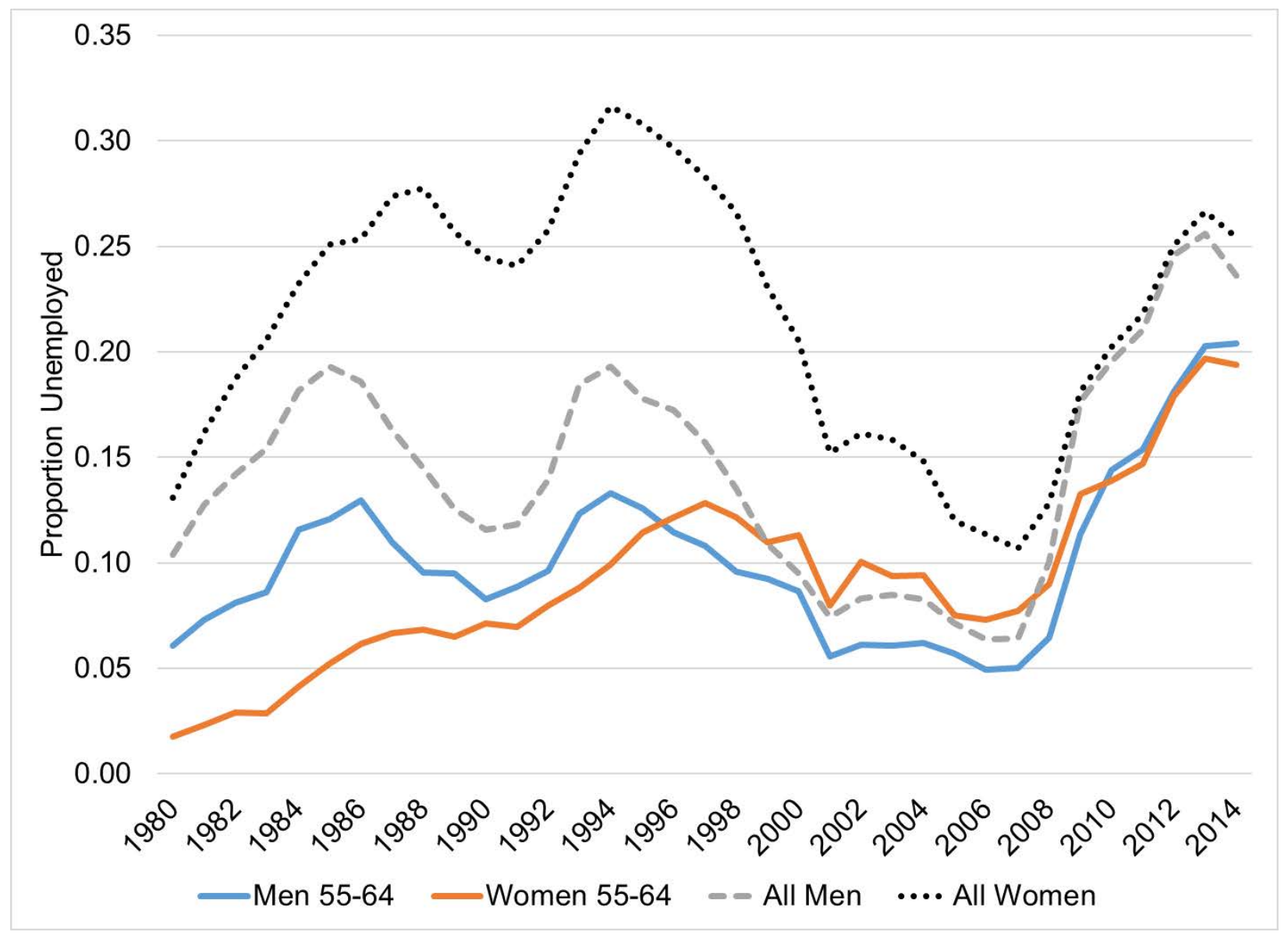

The other exception to the general pattern in Figure 9 is Germany, but there is a policy influence at play in this country. We graph data for Germany on its own in Figure 11 to investigate this case. As explained in the German chapter in this volume, the

\footnotetext{
6 The unemployment rate here is defined as the number of unemployed individuals divided by the sum of employed and unemployed individuals.
} 
enlarged unemployment episode of the 1990s in Germany has its roots in policy as early retirement through extended unemployment benefits became available and popular. This new "bridge to retirement" led to higher reported rates of unemployment among older workers in Germany until 1997, when a new system of actuarial adjustments was phased in, making this option less attractive. Since that time, the rebound in labor force participation for both men and women are among the highest of any of our countries, as documented in Table 2 earlier. This inverse relationship between the unemployment rate and the labor force participation rate is most clear for men, as shown in Figure 11. For women, the story is more complicated by the continued increase of female labor force participation across cohorts.

Figure 11: German Age 55-64 Labor Force Participation and Unemployment

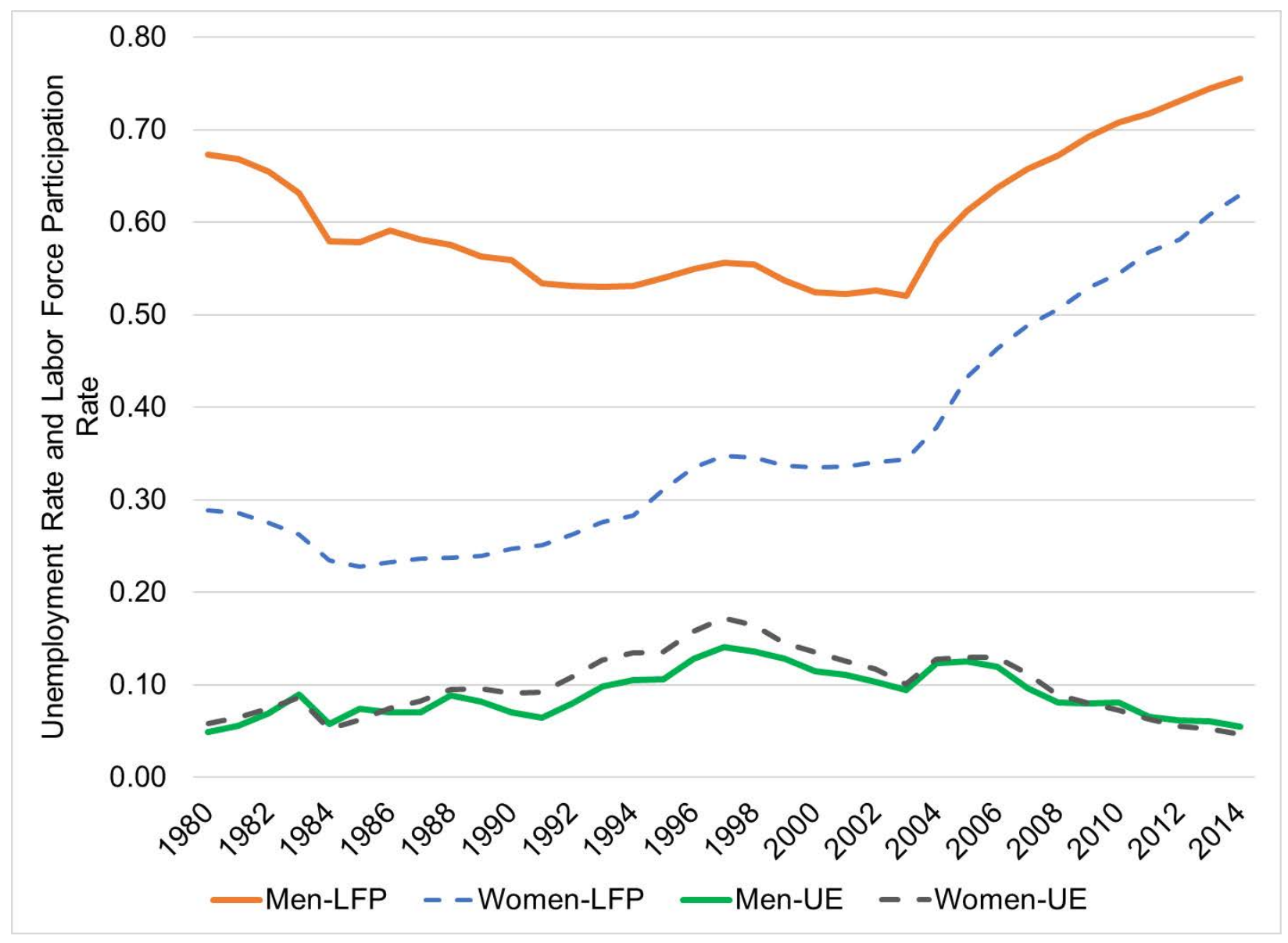

Overall, unemployment does not seem to be a major driver of labor force participation trends. Over all years and countries (omitting Spain and Germany, the case studies just discussed), the average unemployment rate at ages 55-64 is 5.0 percent for men and 4.5 percent for women. Naturally, there are fluctuations in this rate 
with the business cycle as well as some differences across countries, but they appear unrelated to the sustained increases in participation over the past twenty years. However, unusually high levels of unemployment in Spain in recent years may have dampened the increase in participation there, while a German early retirement scheme tied to unemployment appears to have an impact on participation in that country.

\section{Social Security}

Another explanation for the turnaround in labor force participation over the last twenty years comes from the structure of social security benefits. As explored in previous rounds of the International Social Security project (most directly, Gruber and Wise 2004), the structure of social security benefits can induce a behavioral labor supply response among those entering the age range of retirement. If social security reforms over the past several decades have increased the financial incentives for continued work at older ages, this may be responsible for some or even much of the rise in labor force participation since the mid-1990s.

In this round of the International Social Security project, we have not simulated the full dynamic social security incentives-including the timing and the accrual of benefits-that our previous research has shown to be important for retirement decisions. However, we can capture a sense of the importance of these incentives by looking at some simple examples. For ease of exposition, we focus here on three changes in eligibility ages for public pensions, although there are useful discussions of other changes to social security provisions in many of the individual chapters.

In Italy, eligibility ages for retirement benefits for men have increased substantially. As described in more detail in the Italy chapter, a series of reforms first introduced a minimum age (52) for the receipt of early retirement benefits in 1996 (previously, eligibility depended only on having a certain number of contribution years) and then increased it steadily over time, reaching age 63 in 2012. There were also changes to the normal retirement age for men over this period, going from 60 to 66 for men. 
Figure 12: Labor Force Participation and Retirement Ages for Italian Men

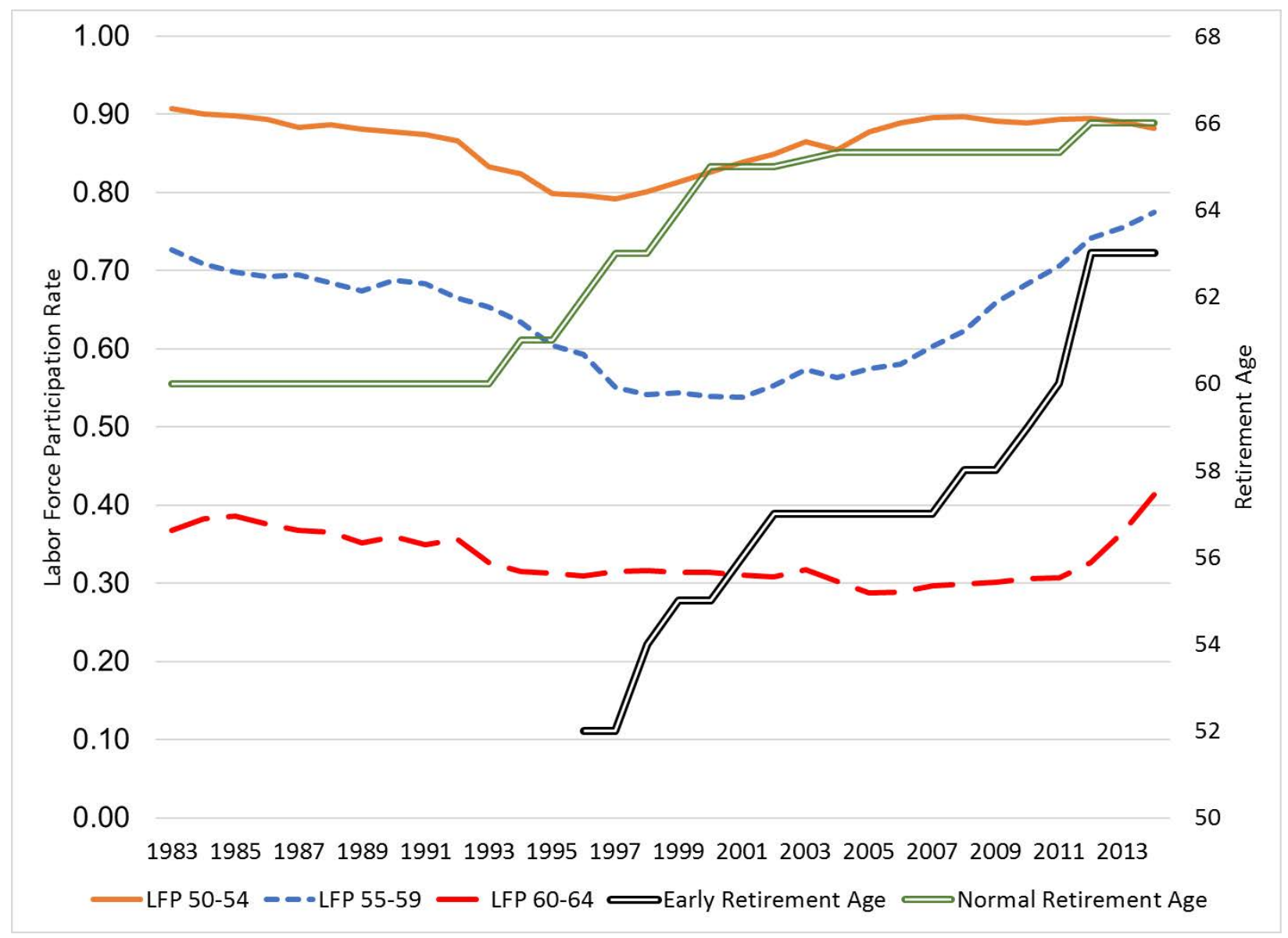

In Figure 12, we graph these statutory retirement ages (right-hand axis) and the labor force participation rates (left-hand axis) for the relevant age ranges for Italian men. At the top, the labor force participation rate at ages 50-54 begins to rise almost exactly when the minimum age for early retirement benefits is introduced in 1996. In the last ten years of our graph when the early retirement age is already far above age 54 , there is little more increase in the age 50-54 labor force participation rate. For ages 55-59, there is a strong increase in participation from 54 percent in 2001 to 78 percent in 2014. Of note, the early retirement age started affecting this age range in 2000 , almost exactly when the labor force participation rate began increasing. Finally, the age 60-64 labor force participation rate begins increasing in 2012, just as the early retirement eligibility age jumped from age 60 to age 63 . Taken together, the timing of the changes in the labor force participation rate for Italian men moves in tight synchronicity with the upticks in the early retirement age, which suggests a strong relationship of social security incentives with the upswing in labor force participation for older men in Italy. 
A similar story can be told in the case of Japan. For women, the eligibility age for both the flat-rate and wage-based components of the pension rose from age 55 to 60 in a series of steps starting in 1987, in order to match the eligibility age for men. There was a further increase in the eligibility age for the flat-rate benefit only starting in 2006 that affected both men and women. Figure 13 juxtaposes the labor force participation rate for women ages 55-59 (left panel) and ages 60-64 (right panel) with the change in eligibility age. As the figure illustrates, the participation rate at ages 55-59 began to rise in the late 1980s, along with the rise in the eligibility age. For women ages 60-64, who were not directly effected by the initial increase in the eligibility age, participation remained flat until the mid-2000s and then began to rise once the eligibility age for the flat-rate benefit began to increase from 60 to 64 . Results for men, shown in the chapter for Japan, reflect a similar increase in participation at ages 60-64 starting in the mid2000 s, also very likely related to the increase in the eligibility age during this period.

Figure 13: Labor Force Participation and Retirement Ages for Japanese Women
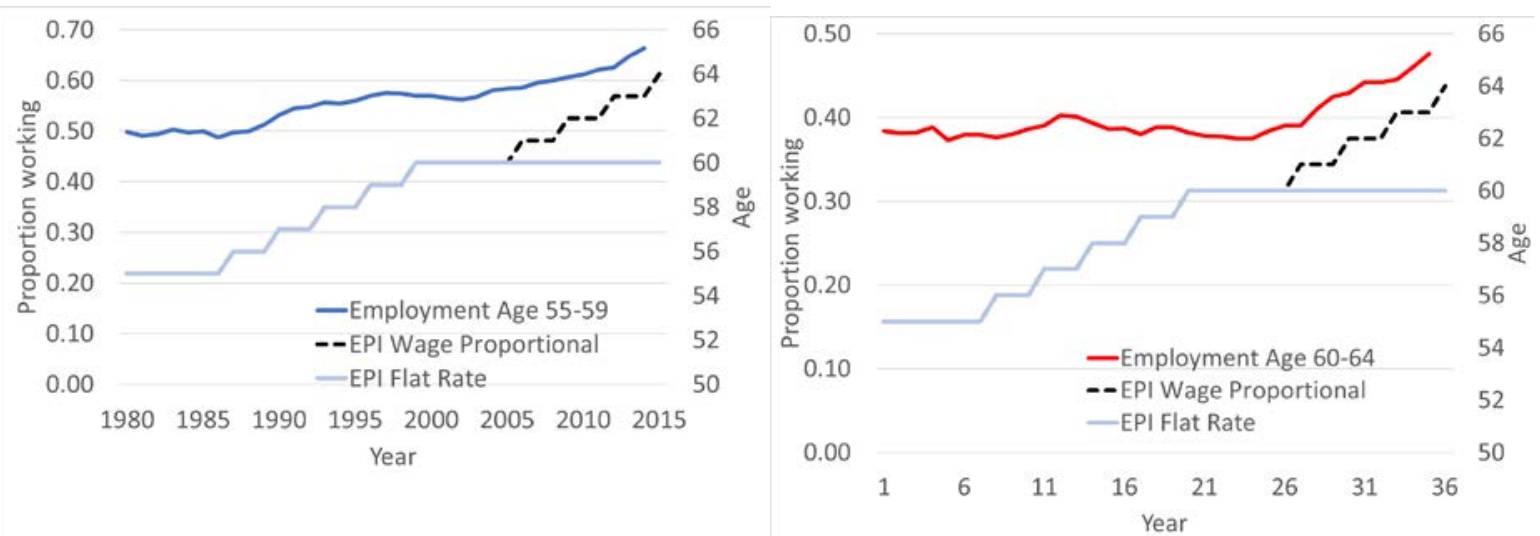

A final example comes from the UK, which has increased the state pension age for women from 60 to 65 in a series of steps. Figure 14 shows the labor force participation rate for women at single ages from 56 to 63 over the period 2003 to 2015 . A striking pattern emerges. When the pension age was raised from 60 to 61 in 2010, participation at age 60 rose by 10 percentage points over the next two years. A similarly large and rapid increase in participation was seen at age 61 once the pension age was raised to 62 in 2012 and at age 62 once the pension age was raised to 63 in 2014. Aside from these three sharp increases, participation rates remained flat or rose only slowly throughout this period. The simultaneity of the eligibility age increases and surges in participation makes a strong case that pension reform is a key driver of higher participation among UK women. More generally, these three examples clearly indicate that social security provisions such as the eligibility age can exert an important influence on labor force participation at older ages. 
Figure 14: Labor Force Participation for UK Women by Exact Age (Ages 56 to 63)

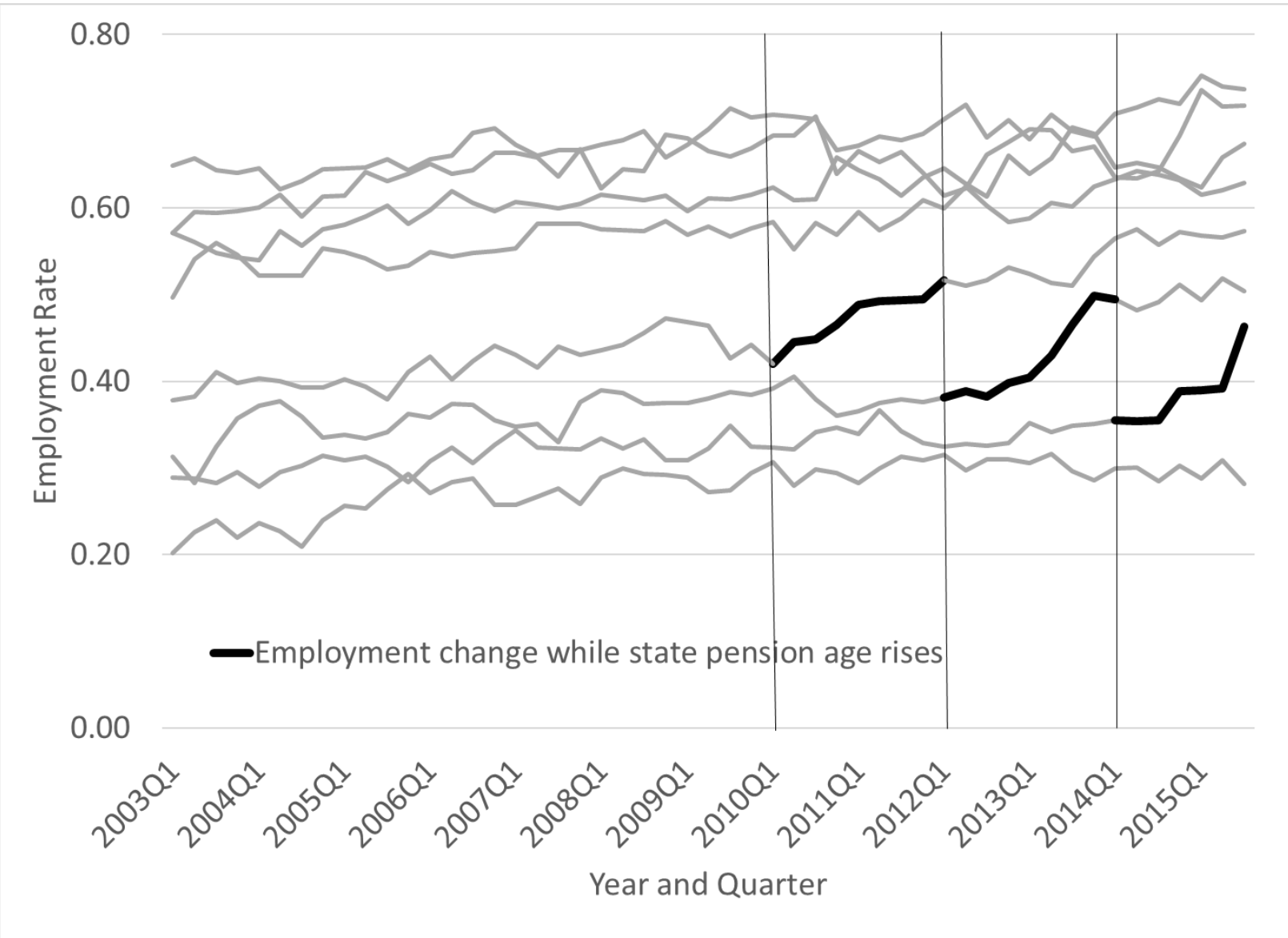

Women's Labor Force Participation

The next factor to consider is the impact of increasing labor force participation by women. While this increase is important on its own, the increase in work by older women over the last twenty years also has a potential impact on men. If married couples prefer to retire at the same time, women working later into their life might keep men later in the workforce. This hypothesis was explored in depth for the cases of Canada, the US, and the UK by Schirle (2008), who finds that it explained between one quarter and one half of the change in labor force participation by married men.

This channel is potentially important for explaining the upswing in male labor force participation after 1995 because the men arriving at ages 55-64 in the mid-1990s were married to women that had much greater labor force participation throughout their lives than earlier cohorts. This is shown in Figure 13 below, where we graph the labor force participation of women ages $35-44$, lagged by twenty years. These women were ages 55-64 in the year shown, and so these numbers give an indication of the proportion of men in the age range 55-64 married to women with substantial lifetime 
labor force attachment. We focus on this measure rather than on the current participation of women ages 55-64 because the latter may be influenced by other factors, such as changes in social security provisions, that are also affecting older men's participation. Over the period 1995 to 2014, the average labor force participation of women (using our age 35-44 twenty-year lag) across our twelve countries grew dramatically, from 50 to 72 percent.

Figure 15: Labor Force Participation of Females age 35-44, lagged twenty years

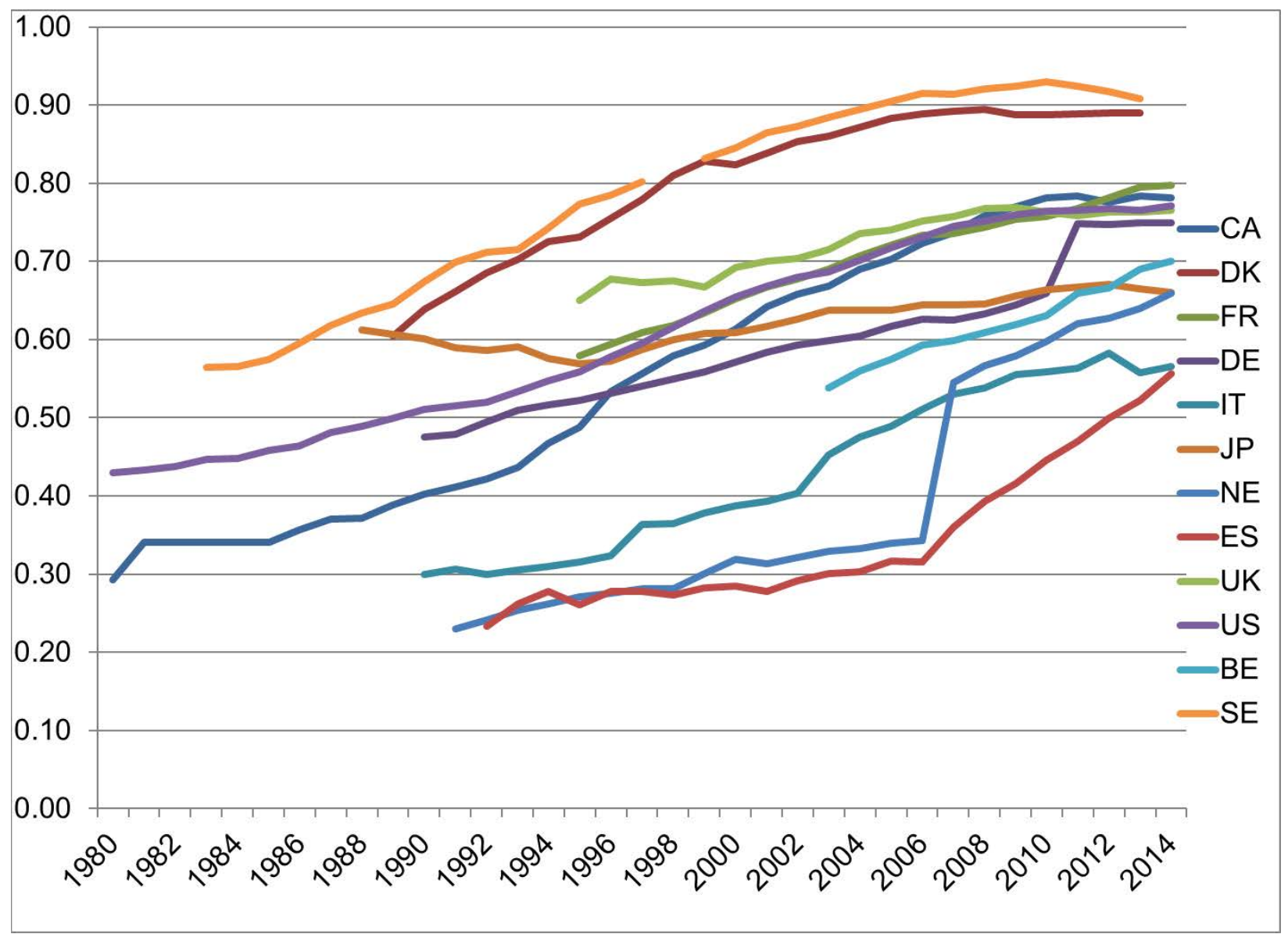

To explore the potential impact of this trend on men's participation, in Figure 16 we provide a scatter plot of the changes between 1995 and 2014 in male labor force participation at ages 60-64 compared to the changes in female labor force participation lagged twenty years. There is a clear and strong positive relationship evident here, with a coefficient on the trend line of 0.81 . The magnitude of this coefficient suggests that having the participation of women (at a younger age) rise by an additional 10 percentage points over time is associated with an 8 point increase in the participation of 
older men. This provides additional support for the Schirle (2008) hypothesis about male labor force participation and working spouses.

Figure 16: Change in LFP for Men 60-64 vs. Change in Lagged Women's LFP, 1995-2014

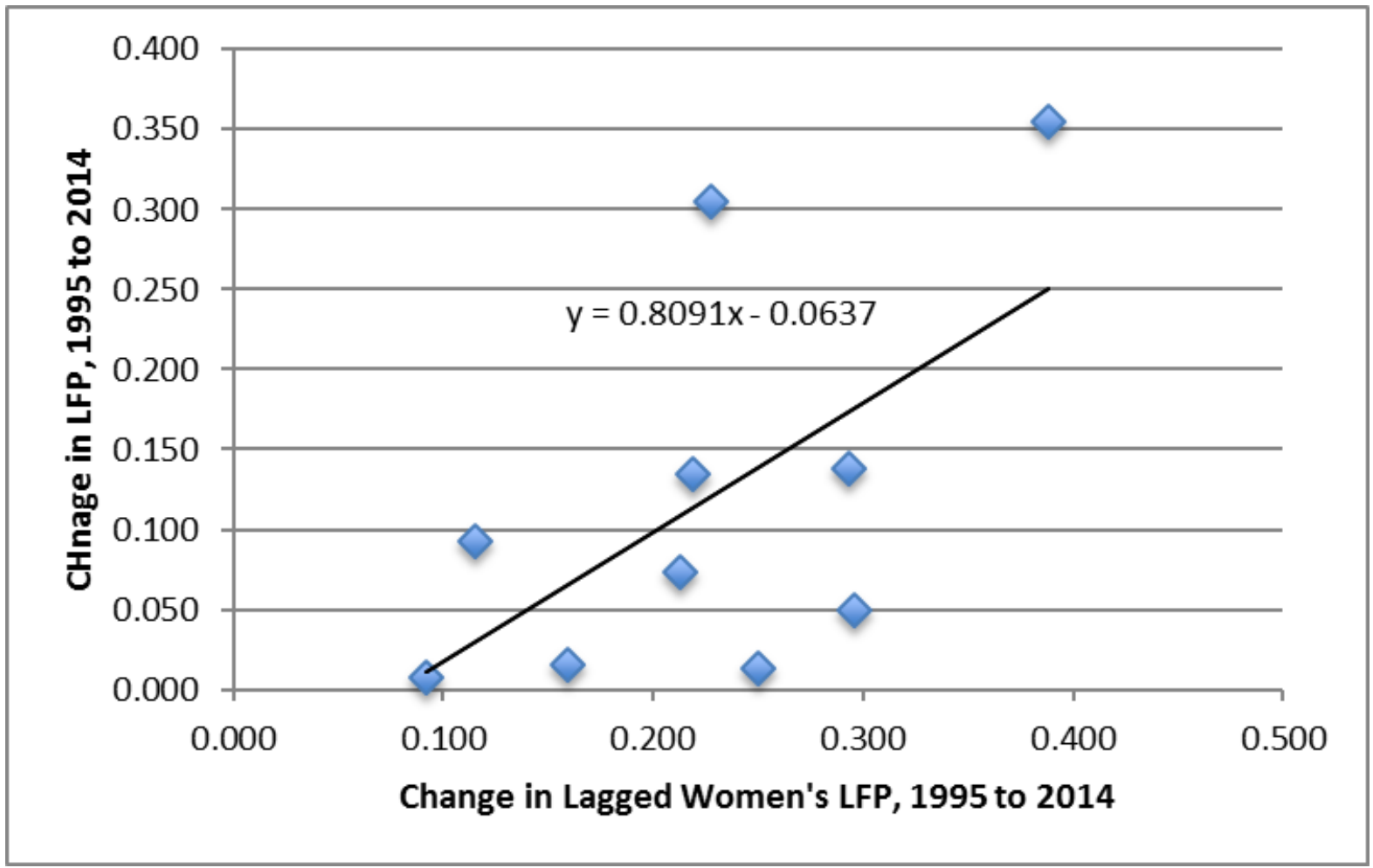

In Figure 17, we recreate the analysis presented in the Canadian chapter based on the methods of Schirle (2008). The analysis takes the observed labor force participation of males ages 55-64 from 1995 to 2015 and makes some adjustments. In the middle line, the adjustment accounts for changes in the age and education structure of the male population over this period. The bottom line makes a further adjustment by imposing the counterfactual that the labor force participation of wives stayed constant at the 1995 rate instead of increasing as it actually did. The results are striking. The increase in actual men's labor force participation is 13.8 percentage points from 1995 to 2015. This increase would have been 1.1 points smaller (12.7 points) if there had been no changes in men's education and age composition. Keeping wives' labor force participation constant at the 1995 level would have reduced the growth in men's participation by a further 4.6 percentage points. This suggests that the working wife effect alone accounts for 33 percent of the increase in male labor force participation during these two decades, while changes in men's education and age explain only 8 percent of the increase. 
Figure 17: Labor Force Participation of Canadian males age 55-64

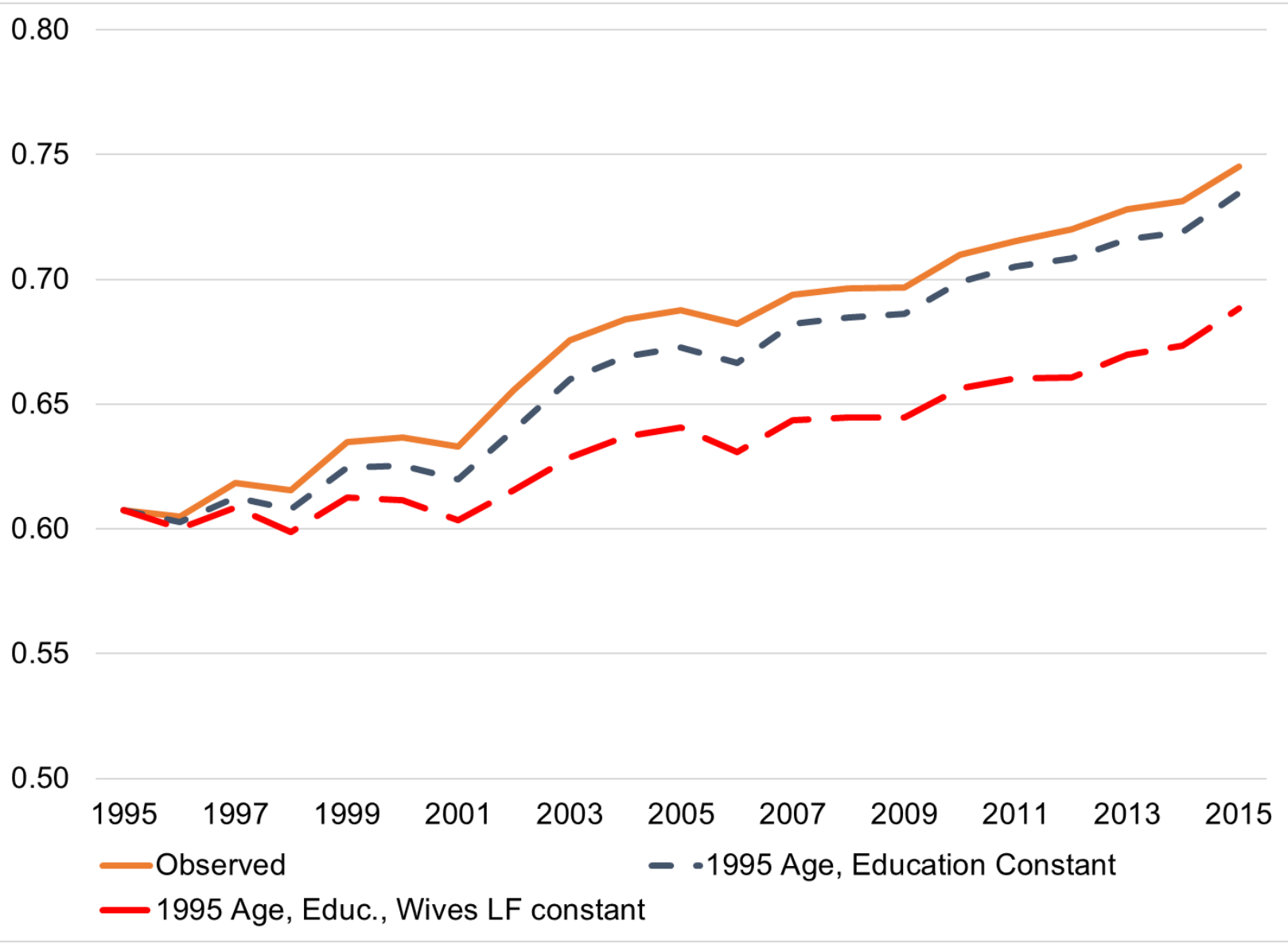

\section{Cross-country regressions}

To summarize our findings, we run some cross-country regressions incorporating all the contributing factors we discuss above. The dependent variable for the regression analysis is the labor force participation rate in the 55-64 age range, for a given year and country. Regressions are estimated separately by sex and include a full set of year and country dummies. We progressively add explanatory variables including the social security normal and early retirement age, the log of the mortality rate, the proportion with college education, lagged female labor force participation rates, the blue collar share, and the overall unemployment rate. The number of observations changes across specifications because of missing data for some of the explanatory variables in certain years and countries. The time period covered here is 1980 to 2014 . While we view this analysis as primarily descriptive, it may nonetheless be useful to examine the association between each factor and participation in a context that incorporates other factors as well. 
Table 3:Cross-Country Regressions for Men

\begin{tabular}{|c|c|c|c|c|c|c|}
\hline & (1) & (2) & (3) & (4) & (5) & $(6)$ \\
\hline Normal Retirement Age & $\begin{array}{c}0.011 \\
(0.007)\end{array}$ & $\begin{array}{c}0.013 \\
(0.007)\end{array}$ & $\begin{array}{l}-0.038 \\
(0.029)\end{array}$ & $\begin{array}{c}0.006 \\
(0.007)\end{array}$ & $\begin{array}{l}-0.005 \\
(0.015)\end{array}$ & $\begin{array}{l}-0.008 \\
(0.017)\end{array}$ \\
\hline Early Retirement Age & $\begin{array}{l}-0.002 \\
(0.005)\end{array}$ & $\begin{array}{l}-0.004 \\
(0.006)\end{array}$ & $\begin{array}{l}-0.004 \\
(0.014)\end{array}$ & $\begin{array}{l}-0.002 \\
(0.004)\end{array}$ & $\begin{array}{c}0.001 \\
(0.007)\end{array}$ & $\begin{array}{c}0.004 \\
(0.005)\end{array}$ \\
\hline Log mortality & & $\begin{array}{l}-0.048 \\
(0.142)\end{array}$ & & $\begin{array}{l}-0.022 \\
(0.120)\end{array}$ & $\begin{array}{l}-0.054 \\
(0.074)\end{array}$ & $\begin{array}{c}0.088 \\
(0.061)\end{array}$ \\
\hline Self-assessed health fair-poor & & & $\begin{array}{c}0.226 \\
(0.283)\end{array}$ & & & \\
\hline College share & & & & $\begin{array}{c}0.001 \\
(0.002)\end{array}$ & $\begin{array}{c}0.002 \\
(0.002)\end{array}$ & $\begin{array}{c}0.002 \\
(0.001)\end{array}$ \\
\hline Women LFP, lagged 20 years & & & & & $\begin{array}{c}0.244 \\
(0.120)^{\star}\end{array}$ & $\begin{array}{c}0.169 \\
(0.036)^{\star \star \star}\end{array}$ \\
\hline Blue collar share & & & & & & $\begin{array}{c}0.151 \\
(0.209)\end{array}$ \\
\hline Unemployment rate & & & & & & $\begin{array}{c}-0.353 \\
(0.088)^{\star \star \star}\end{array}$ \\
\hline Year dummies & YES & YES & YES & YES & YES & YES \\
\hline Country dummies & YES & YES & YES & YES & YES & YES \\
\hline R-Squared & 0.917 & 0.922 & 0.900 & 0.940 & 0.937 & 0.979 \\
\hline Observations & 324 & 312 & 160 & 278 & 228 & 173 \\
\hline
\end{tabular}

Notes: Data are drawn from our twelve countries over the time period 1980-2014, although not all data are available for all countries in all years. Each column reports results from a separate regression. The dependent variable is the share in the labor force at age 55-64. We report the coefficient for each variable listed, with the standard error in parentheses below. The standard errors are robustadjusted and clustered by country. All specifications include both year and country dummies. 


\begin{tabular}{|c|c|c|c|c|c|c|}
\hline & (1) & (2) & (3) & (4) & $(5)$ & $(6)$ \\
\hline Normal Retirement Age & $\begin{array}{c}0.009 \\
(0.005)\end{array}$ & $\begin{array}{c}0.006 \\
(0.006)\end{array}$ & $\begin{array}{l}-0.014 \\
(0.019)\end{array}$ & $\begin{array}{c}0.005 \\
(0.004)\end{array}$ & $\begin{array}{c}0.000 \\
(0.006)\end{array}$ & $\begin{array}{l}-0.001 \\
(0.009)\end{array}$ \\
\hline Early Retirement Age & $\begin{array}{l}-0.009 \\
(0.004)^{\star}\end{array}$ & $\begin{array}{c}-0.009 \\
(0.004)^{\star \star}\end{array}$ & $\begin{array}{l}-0.006 \\
(0.011)\end{array}$ & $\begin{array}{c}-0.010 \\
(0.003)^{\star *}\end{array}$ & $\begin{array}{l}-0.002 \\
(0.004)\end{array}$ & $\begin{array}{c}0.001 \\
(0.003)\end{array}$ \\
\hline Log mortality & & $\begin{array}{c}0.102 \\
(0.060)\end{array}$ & & $\begin{array}{c}0.045 \\
(0.046)\end{array}$ & $\begin{array}{c}0.055 \\
(0.046)\end{array}$ & $\begin{array}{c}0.048 \\
(0.029)\end{array}$ \\
\hline Self-assessed health fair-poor & & & $\begin{array}{c}0.120 \\
(0.211)\end{array}$ & & & \\
\hline College share & & & & $\begin{array}{c}0.000 \\
(0.001)\end{array}$ & $\begin{array}{l}-0.001 \\
(0.001)\end{array}$ & $\begin{array}{c}0.000 \\
(0.001)\end{array}$ \\
\hline Women LFP, lagged 20 years & & & & & $\begin{array}{c}0.408 \\
(0.057)^{\star \star \star}\end{array}$ & $\begin{array}{c}0.371 \\
(0.112)^{\star \star}\end{array}$ \\
\hline Blue collar share & & & & & & $\begin{array}{c}0.162 \\
(0.202)\end{array}$ \\
\hline Unemployment rate & & & & & & $\begin{array}{c}-0.321 \\
(0.105)^{\star \star}\end{array}$ \\
\hline Year dummies & YES & YES & YES & YES & YES & YES \\
\hline Country dummies & YES & YES & YES & YES & YES & YES \\
\hline R-Squared & 0.941 & 0.946 & 0.937 & 0.952 & 0.961 & 0.979 \\
\hline Observations & 324 & 312 & 144 & 262 & 215 & 166 \\
\hline
\end{tabular}

Notes: Data are drawn from our twelve countries over the time period 1980-2014, although not all data are available for all countries in all years. Each column reports results from a separate regression. The dependent variable is the share in the labor force at age 55-64. We report the coefficient for each variable listed, with the standard error in parentheses below. The standard errors are robustadjusted and clustered by country. All specifications include both year and country dummies. 
The results are presented for men in table 3 and women in table 4 . In the first column we just include the statutory retirement ages, along with the country and year dummies. There is no clear statistical relationship apparent here for men or women. This is at some contrast to the experience of the individual cases of countries discussed above where there was a clear relationship between changes in the statutory ages and older worker labor force participation. Using a broad age range may explain the lack of significant results here-a more granular age-by-age analysis (as suggested by the Italy and UK examples) and the more detailed modeling of financial incentives that characterized previous ISS research may be better suited to picking up the influence of social security rules.

In column (2), we add a control for health through the log mortality rate. Again, there is no clear relationship available to be seen. In column (3) we use the share of respondents reporting fair or poor health, which results in a large drop in the sample size because of many countries with missing data for this variable. There is no evidence of a strong relationship with this alternative measure of health. To maintain a larger sample, we continue with the log mortality measure in the subsequent columns. We add the share with college education in column (4). There is not a clear relationship for either men or women.

In the fifth column we add the female labor force participation rate, lagged twenty years to account for differences in cohort labor market participation by women over the years. We examined this explanatory factor earlier for the case of Canada. Here, there is a statistically significant positive relationship for both men and for women. For men, the estimated impact is 0.244 , meaning that for every one percentage point increase in cohort female labor force participation, male labor force participation increases by about a quarter of a point. For females, the effect is stronger at 0.408 , as might be expected given that this captures the effect of higher past participation on the women themselves rather than the spillover effect on their spouses.

In the final column we include the share in blue-collar occupations and the (all age) unemployment rate. We lose many countries here because of lack of data for the blue-collar occupations, and as noted earlier this variable may capture different swaths of the population in different countries. The blue-collar rate does not have a statistically significant effect for either men or women. In contrast, the unemployment rate is strongly significant for men and women, embodying the strong pro-cyclical pattern between elderly labor force participation and unemployment rates seen earlier.

This regression evidence is meant to summarize the discussion of the individual factors in this introductory chapter, and provide motivation for future work. The clearest cross-country impacts seem to come from trends in female labor force participation and general business cycle effects. There is no evidence for health or occupational impacts 
on broad labor force participation. For the institutional factors, we do not find evidence of an effect based on a fairly crude analysis that only includes eligibility age variables. It remains for future work to undertake a more detailed analysis looking more deeply at the full range of institutional incentive effects, as was done in previous analyses of the international social security project, and which may well uncover a stronger relationship.

\section{Conclusion}

This volume continues the work of the International Social Security project by documenting and investigating the upswing in labor force participation among older workers over the last two decades. We show that the rise in participation for both men and women is substantial and is evident in all twelve countries that are part of the project. The nature and timing of these changes is surprisingly similar across countries, with a U-shaped pattern for men that generally reaches its minimum in the mid-1990s and a much shallower $U$ or continuously rising pattern for women. There are important differences across countries in the magnitude of the increase, as well as in whether the largest change occurred at relatively young (age 55-59), middle (age 60-64), or older (age 65-69) ages.

We also examine different potential explanations for the upswing, including changes in health, education, occupational mix, unemployment, and social security rules and incentives. All of these factors have changed substantially over the past two decades, making it important to assess their role in explaining labor force trends. Perhaps surprisingly, despite the well-known association between health or education and retirement at the individual level, we find little evidence that improvements in these factors are key drivers of the increases in participation over time. We base this conclusion on the fact that these factors have tended to improve both during times when participation has been rising as well as falling; further, those countries with the largest improvements in health or education have not necessarily experienced the largest increases in participation. While our analysis does not rule out the possibility of a role for these factors, it does suggest that they alone almost certainly cannot explain the large increases in participation over the past two decades. We similarly conclude that unemployment is not a major part of the story, though it may have been important in a few of our countries.

We find more evidence that the increase in female labor force participation across generations has had an important pull on male labor force participation. While we are naturally cautious about drawing causal implications from our simple analysis, this variable is significant in our cross-country regressions and there is a strong positive association between changes in lagged women's labor force participation and in older men's participation across countries. Past work such as Schirle (2008) supports the conclusion that this factor has likely played a role. 
Finally and perhaps most importantly, in particular country examples throughout this volume, some of which we discuss above, there is strongly suggestive evidence that social security rules like statutory retirement ages can also change labor market attachment. While we fail to find significant effects of these eligibility ages in our crosscountry regressions, we attribute this finding to the simplicity of our analysis. Past studies in this project (notably, Gruber and Wise 1999 and 2004; Wise, 2016) as well as the work of many others have consistently found that social security incentives matter for retirement. In our past work, we have relied on differences across countries at a point in time (Gruber and Wise, 1999) and on differences across individuals within countries (Gruber and Wise, 2004) to uncover this relationship. In the two decades since this project began, many countries have enacted social security reforms. This offers a rich opportunity to make use of these reforms, which generate differences in social security incentives within countries over time, to revisit the role of social security program provisions on retirement behavior.

In sum, many important questions remain to be answered. How much of the reversal in labor force participation that we document here may be attributable to changes in social security rules? What are the relative roles of statutory retirement ages versus other program changes, such as to actuarial adjustments and benefit formulas? Future work of the international social security project will examine these questions directly. 


\section{References}

Belbase, Anek, Geoffrey Sanzenbacher, and Christopher Gillis (2016). "How Do Job Skills that Decline with Age Affect White-Collar Workers?" Center for Retirement Research at Boston College Issue Brief No. 16-6, April.

Bell, Felicity and Michael Miller (2002). "Life Tables for the United States Social Security Are 1900-2100," Social Security Administration Actuarial Study No. 116.

Chernew, Michael, David Cutler, Kaushik Ghosh, and Mary Beth Landrum (2016). "Understanding the Improvement in Disability Free Life Expectancy in the U.S. Elderly Population," NBER Working Paper No. 22306, June.

Coile, Courtney, Kevin Milligan, and David Wise (2016). "Introduction and Summary," in David Wise, ed., Social Security Programs and Retirement Around the World: Disability Insurance Programs and Retirement. Chicago: University of Chicago Press.

Costa, Dora (1998). The Evolution of Retirement: An American Economic History, 18801990. Chicago: University of Chicago Press.

Crimmins, E.M. and H. Beltran (2011). "Is There Compression of Morbidity?" Journal of Gerontology: Social Sciences, 66B(1):75-86.

Cutler, David, Kaushik Ghosh, and Mary Beth Landrum (2014). "Evidence for Significant Compression of Morbidity in the Elderly U.S. Population," in David A. Wise, ed., Discoveries in the Economics of Aging. Chicago: University of Chicago Press.

Diamond, Peter and Jerry Hausman (1984). "The Retirement and Unemployment Behavior of Older Men," in Gary Burtless and Henry Aaron, eds., Retirement and Economic Behavior. Washington, D.C.: Brookings Institution Press.

Goldin, Claudia (2006). "The Quiet Revolution that Transformed Women's Employment, Education, and Family," American Economic Review 96(2):1-21.

Gruber, Jonathan and David A. Wise (1999). Social Security and Retirement Around the World. Chicago: University of Chicago Press.

Gruber, Jonathan and David A. Wise (2004). Social Security Programs and Retirement Around the World: Microestimation. Chicago: University of Chicago Press.

Gruber, Jonathan and David A. Wise (2007). Social Security Programs and Retirement Around the World: Fiscal Implications of Reform. Chicago: University of Chicago Press. 
Gruber, Jonathan and David A. Wise (2010). Social Security Programs and Retirement Around the World: The Relationship to Youth Employment. Chicago: University of Chicago Press.

Milligan, Kevin and David Wise (2012). "Introduction and Summary," in David Wise, ed., Social Security Programs and Retirement Around the World: Historical Trends in Mortality and Health, Employment, and Disability Insurance Participation and Reforms. Chicago: University of Chicago Press.

Schirle, Tammy (2008). "Why Have the Labor Force Participation Rates of Older Men Increased since the Mid-1990s?", Journal of Labor Economics, Vol. 26, No. 4, pp. 549-594

Wise, David A. (2012). Social Security Programs and Retirement Around the World: Historical Trends in Mortality and Health, Employment, and Disability Insurance Participation and Reforms. Chicago: University of Chicago Press.

Wise, David A. (2016). Social Security Programs and Retirement Around the World: Disability Insurance Programs and Retirement. Chicago: University of Chicago Press.

Wise, David A. (2017). Social Security Programs and Retirement Around the World: The Capacity to Work at Older Ages. Chicago: University of Chicago Press. 